\title{
Spatiotemporal Distributions of Non-ophidian Ophidiomorphs, With Implications for Their Origin, Radiation, and Extinction
}

\section{OPEN ACCESS}

Edited by:

K. Christopher Beard,

University of Kansas, United States

Reviewed by:

John David Scanlon,

University of New South Wales,

Australia

Spencer G. Lucas,

New Mexico Museum of Natural History and Science, United States

*Correspondence:

Michelle Campbell Mekarski mmc7@ualberta.ca

Specialty section:

This article was submitted to

Paleontology,

a section of the journal

Frontiers in Earth Science

Received: 01 November 2018 Accepted: 03 September 2019 Published: 24 September 2019

Citation:

Campbell Mekarski M, Pierce SE and Caldwell MW (2019)

Spatiotemporal Distributions of Non-ophidian Ophidiomorphs, With Implications for Their Origin,

Radiation, and Extinction.

Front. Earth Sci. 7:245

doi: 10.3389/feart.2019.00245

\section{Michelle Campbell Mekarski ${ }^{1 *}$, Stephanie E. Pierce ${ }^{2}$ and Michael W. Caldwell ${ }^{1,3}$}

${ }^{1}$ Department of Biological Sciences, University of Alberta, Edmonton, AB, Canada, ${ }^{2}$ Museum of Comparative Zoology and Department of Organismic Biology, Harvard University, Cambridge, MA, United States, ${ }^{3}$ Department of Earth and Atmospheric Sciences, University of Alberta, Edmonton, AB, Canada

Non-ophidian ophidiomorphs, colloquially referred to as 'dolichosaurs,' are small-bodied aquatic lizards that lived in shallow seaways, rivers, and reef environments during the Late Cretaceous. Preservational, geographic, and taphonomic biases in this group make trends in biodiversity difficult to assess. This is exemplified by the fact that the majority of the described species are monotypic and known only from single specimens, imparting very little information on morphological or spatial variation. Here we present a revision of the spatial and temporal distributions of non-ophidian ophidiomorph lizards ('dolichosaurs') from Cretaceous sediments worldwide. The fossil record of dolichosaurs begins in the Valanginian (Early Cretaceous). The late Early Cretaceous records are sparse but suggest a wide geographic distribution spanning the Tethys and Western Pacific. This is followed by a dense Cenomanian record from Tethyan and British deposits, and rarer specimens from North America. Though there is a substantial drop in the number of specimens recorded from the Turonian-Maastrichtian, these rare occurrences represent the largest geographical distribution of dolichosaurs: spanning Europe, North America, and South America before going extinct during the endCretaceous mass extinction. These occurrences indicate that ophidiomorphs most likely originated in the Jurassic Tethys and continued to radiate spatially and phylogenetically until the end of the Mesozoic, showing much more temporally and environmentally diverse patterns than previously indicated.

Keywords: palaeoecology, distribution, ophidiomorphs, dolichosaurs, cretaceous, spatiotemporal, Squamata

\section{INTRODUCTION}

The early Late Cretaceous is undoubtedly one of the most interesting periods in the evolution of squamates. Primarily terrestrial throughout their evolutionary history, Squamata underwent a unique and spectacular aquatic radiation into the marine realm during the Late Cretaceous. This radiation was accomplished primarily by two groups: Mosasauroidea (aigialosaurs and mosasaurs; see Caldwell, 2012) and Ophidiomorpha (snakes and dolichosaurs; see Palci and Caldwell, 2010). Dolichosaurs (Figure 1) represent a phylogenetically contentious group of elongate, limb reduced, marine lizards closely aligned to mosasaurs and snakes (Lee and Caldwell, 2000; Pierce and Caldwell, 2004). They are small-less than a meter in length-and are generally considered to be semi-aquatic piscivores (Camp, 1923; Caldwell, 1999, 2000; Caldwell and Cooper, 1999; 


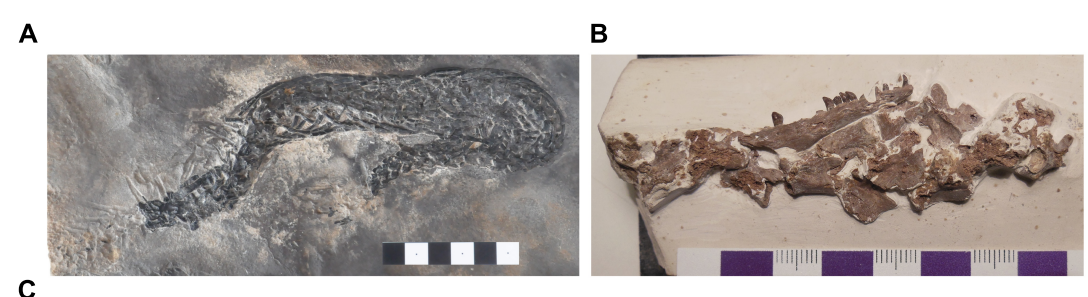

C
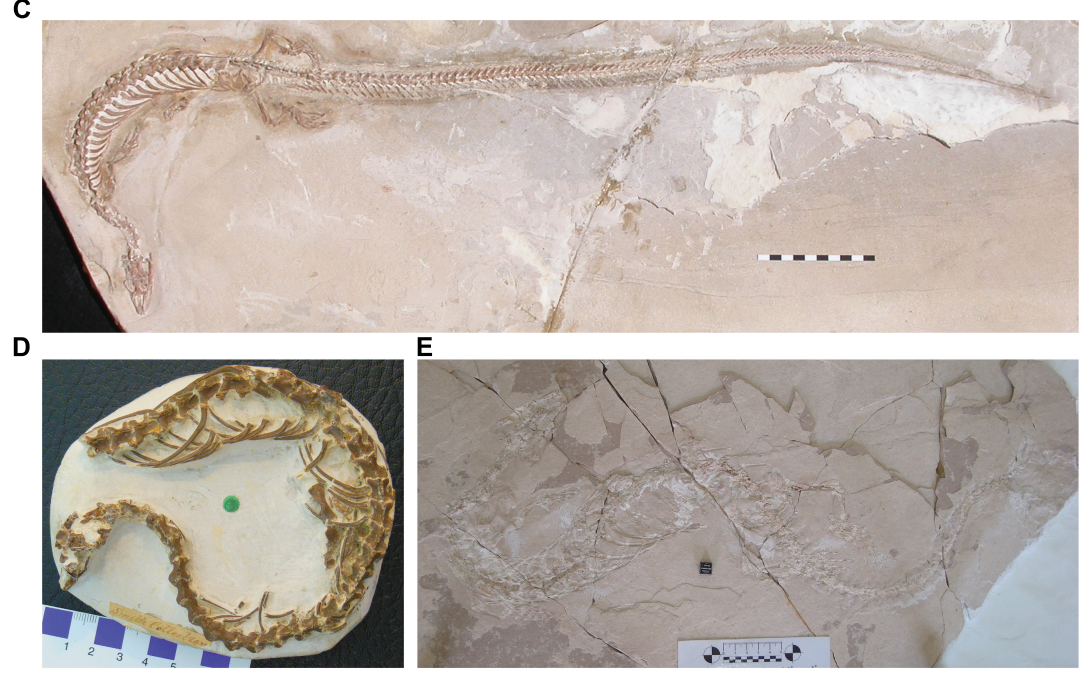

FIGURE 1| A selection of dolichosaur fossils. (A) Adriosaurus skrbinensis (SMNH 2158); (B) Conisasaurus crassidens (BMB 007155); (C) Pontosaurus kornhuberi (MSNM V3662); (D) Dolichosaurus longicollis (BMNH R 49002); (E) Primitivus manduriensis (MPUR NS 161).

Lee and Caldwell, 2000; Caldwell and Dal Sasso, 2004; Palci and Caldwell, 2007, 2010). Dolichosaurs are diagnosable by their elongate necks ( $>10$ cervical vertebrae), elongate trunks (>35 presacral vertebrae), zygosphene-zygantra articulations throughout the entire presacral region, and a reduction in forelimb elements. Historically grouped into a monophyletic family, Dolichosauridae, which was established for the species Dolichosaurus longicollis (Kramberger, 1892), there are currently 15 species (11 genera) that are generally ascribed to the family.

Nopcsa $(1908,1923)$ was the first to propose that dolichosaurs were more closely related to snakes than to other Cretaceous aquatic squamates (the mosasaurs and aigialosaurs). From the start, this hypothesis was contentious, supported by some (e.g., McDowell and Bogert, 1954) but rejected by others (e.g., Féjérváry, 1918; Camp, 1923). The advent of computer generated cladistic analyses in the 1980's intensified the debate on the relationship of snakes and dolichosaurs. Some recent phylogenetic analyses (Caldwell, 2000; Lee and Caldwell, 2000; Lee and Scanlon, 2002; Pierce and Caldwell, 2004; Palci and Caldwell, 2007, 2010) support Nopcsa's dolichosaur-snake hypothesis, even supporting the establishment of Ophidiomorpha, to contain exclusively dolichosaurs and ophidians (Palci and Caldwell, 2010). However, instead of finding the Dolichosauridae and the Ophidia to be sister groups, these analyses instead recover 'dolichosaurs' as successive sister groups to ophidians. According to this interpretation, dolichosaurs are a paraphyletic assemblage: an evolutionary 'grade' along the road to snakes. Since dolichosaurs are potentially critical to the understanding of snake evolution, it is important to recognize aspects of their palaeoecology as a means of understanding the palaeoecology of snake origins. The logic behind such comparisons is based on the idea that if snakes and dolichosaurs are sister taxa then they must share some features of their common ancestor. Marine adaptations might well be on this list.

The dolichosaur fossil record is spotty, with most material coming from the productive Cenomanian-Turonian localities of Europe and the Western Interior Seaway (Pierce, 2003; Jacobs et al., 2005a,b). This bias is primarily due to commercially quarried Adriatic limestone and a culture of collecting 'curios' in 18th and 19th century Europe which increased chances of discovery in western and southern Europe (Dadić, 1982). However, it is evident that some combination of preservational, geographic, geological, taphonomic, and depositional biases contributes to the poor record of dolichosaurs worldwide. This is exemplified by the fact that many of the described genera are monotypic and many of the described species are known only from a single specimen. Records of these animals consist of articulated specimens on limestone slabs, or isolated elements (usually vertebrae). Non-deposition, highenergy and/or biologically active environments, erosion of major rock units, and the small size of the animals themselves diminish the likelihood of preservation and discovery, and causes underestimations of diversity and abundance (Brown et al., 2013; Cleary et al., 2015).

Despite these factors, recent finds have dramatically altered traditional views of the stratigraphic distribution and global 
range of the dolichosaurs (e.g., Haber and Polcyn, 2005; Hontecillas et al., 2015; Paparella et al., 2018). These new occurrence data indicate that our understanding of the evolution of dolichosaurs needs to be reevaluated. Here, we review the stratigraphy and depositional setting of dolichosaur fossils in order to identify patterns in their distribution, generate a hypothesis of dolichosaur spatiotemporal history and create a paleoenvironmental interpretation that would help to explain their evolutionary history and distribution pattern.

Note on definitions: 'Dolichosaurs'-Several phylogenetic analyses have found dolichosaurs to form a Hennigian Comb as successive sister taxa to snakes (Lee and Caldwell, 2000; Pierce and Caldwell, 2004; Caldwell and Palci, 2010; Palci and Caldwell, 2010). Therefore, the term 'dolichosaur' will be used in this study to refer to non-ophidian ophidiomorphs (elongate, limbed-but limb-reduced-Cretaceous marine squamates) as the term is well understood even though it does not include snakes. In a similar fashion, the term 'aigialosaur' will be used in this study to refer to non-mosasaurid (plesiopedal and plesiopelvic) mosasauroids.

\section{SPATIOTEMPORAL DISTRIBUTION OF DOLICHOSAURS}

\section{Overview}

Historically described as a Cenomanian-Turonian aged group from the Tethys and Western Interior Seaway, dolichosaur fossils have recently been reported from well beyond this spatial and temporal range (Figure 2). These records range from articulated specimens to isolated elements (primarily teeth and vertebrae). Most unarticulated fossils originate from outside the Mediterranean Tethys, and are thus more difficult to reliably assign to a genus or family. Uncertainty is expressed where each report is discussed.

\section{Hauterivian (Lower Cretaceous); Figure 2A \\ Japan}

The geologically oldest proposed dolichosaur is Kaganaias hakusanensis, described from the Kuwajima Formation (Tetori Group) of central Honshu, Japan (Evans et al., 2006). The Kuwajima Formation has been variously dated from the Neocomian (Lower Cretaceous, 146-130 mya), though an upper Hauterivian age is best supported by biostratigraphy and zircon fission-track dating (see Evans et al., 2006 for discussion). The formation alternates between beds of fine-grained sandstones, mudstones, and coarse sandstones (Isaji et al., 2005). The coarse sandstone layers are found with pebbles, gravels and driftwood, and are interpreted to be channel deposits. The fine sandstones and mudstones are the fossil bearing units, containing in situ tree trunks, and interpreted as inter-channel deposits. These layers are dominated by three facies (Isaji et al., 2005): one representing a peat marsh, one a shallow freshwater lake, and the third a subaerial swamp. The fossil lizards originate from two facies: one containing freshwater aquatic invertebrates, fish, turtles, and choristoderes which is interpreted as a freshwater lake; the second with lower concentrations of freshwater aquatic invertebrates, fish, turtles, and choristoderes, and dominated by terrestrial fauna (lizards, mammals, dinosaurs). The latter depositional environment would have been at least $100 \mathrm{~km}$ from the sea, and is interpreted as a vegetated freshwater swamp that was subject to flooding such as could be found on a delta plain or river floodplain.

\section{Barremian (Lower Cretaceous); Figure 2B \\ Spain}

The next oldest record attributed to a dolichosaur comes from the Barremian of Spain (biostratigraphy; Fregenal-Martínez et al., 2017). These isolated vertebrae were initially described as a snake (Rage and Richter, 1994), but additional data on Cretaceous squamates caused the original authors to rescind this referral (Rage and Werner, 1999). It has since been suggested that it is more likely a dolichosaur (Scanlon and Hocknull, 2008). The vertebrae were recovered from near Uña (Cuenca Province, Castilla-La Mancha) in eastern Spain. The site is part of the La Huérguina Formation which preserves a freshwater lacustrine environment (Buscalioni and FregenalMartinez, 2010). This rich lithographic limestone locality produces plants, invertebrates, and complete, fully articulated vertebrates including birds, dinosaurs, pterosaurs, amphibians, turtles, crocodiles, and lizards (Sanz et al., 1988; Evans and Barbadillo, 1997, 1999; Ortego et al., 1999; Bolet and Evans, 2012). The locality is interpreted as a seasonal subtropical wetland ecosystem (Buscalioni and Fregenal-Martinez, 2010).

\section{Albian (Lower Cretaceous); Figure 2C Australia}

A single, incomplete vertebra identified as a dolichosaur (Incertae sedis) comes from the latest Albian of Queensland, Australia (Scanlon and Hocknull, 2008). The specimen originates from the Winton Formation, considered to be latest Albian in age (pollen biostratigraphy; Dettmann and Clifford, 2000). The fossiliferous, silty claystone associated with this find has produced extensive fossil remains including plants, insects, mollusks, lungfish, turtles, crocodilians, pterosaurs, and dinosaurs. The formation is an extensive fluvial sequence composed of several fossiliferous horizons. The larger elements associated with the dolichosaur remains include bones that have been reworked and transported, indicating an active system at the time of the dolichosaur's deposition (Exon and Senior, 1976; Scanlon and Hocknull, 2008).

\section{Cenomanian (Upper Cretaceous); Figure 2D} Overview of Cenomanian Distribution

By far the highest concentrations of discovered dolichosaurs are Cenomanian in origin. All originate from two seaways: the majority from the Tethys and surrounding regions, and the remainder from the Western Interior Seaway.

In the Late Cretaceous, a transgressive phase of the Tethys Sea covered much of Europe (including Western Europe, the Mediterranean region, and Eastern Europe), the Middle East, and northeastern Africa (Hancock and Kauffman, 1979; 


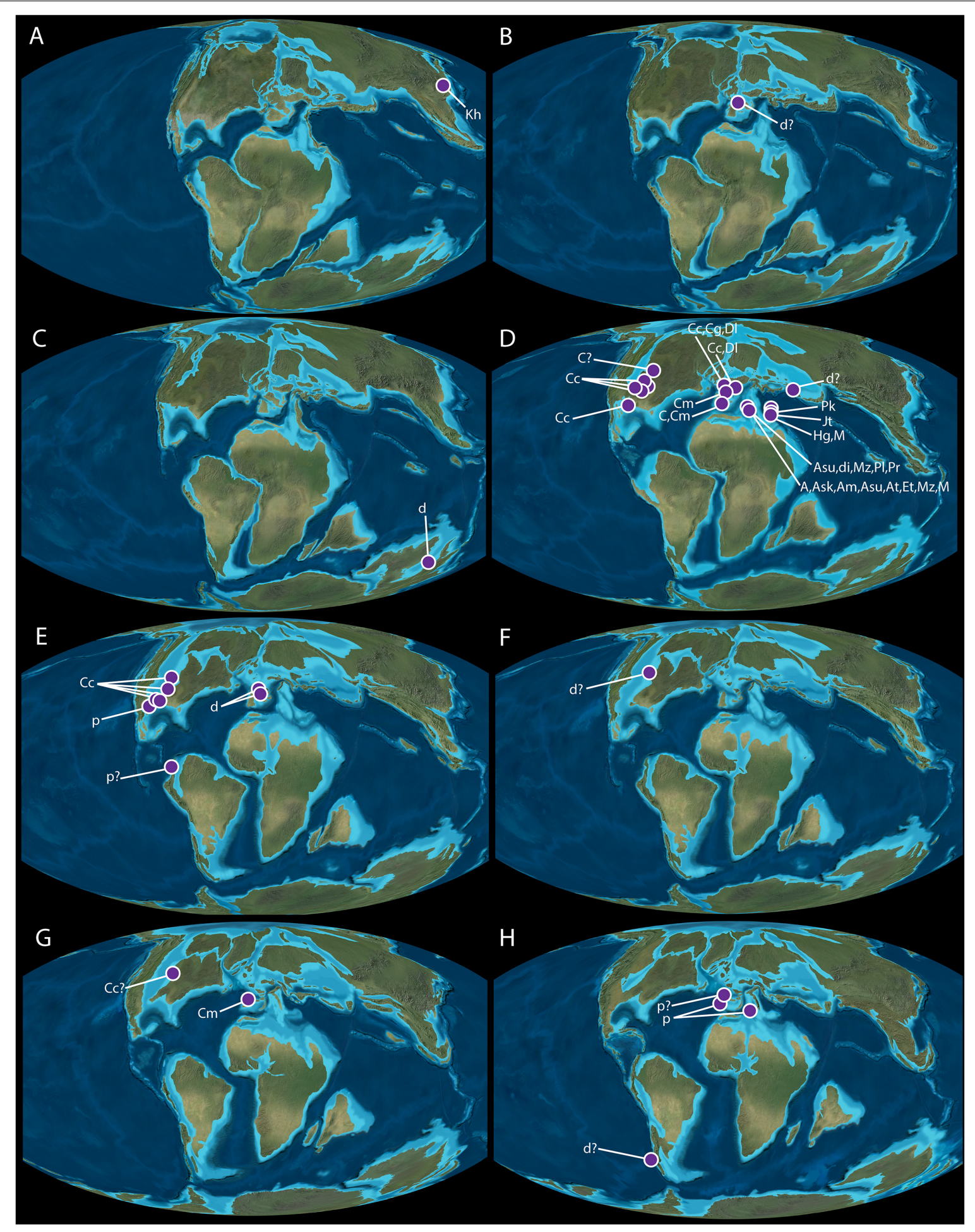

FIGURE 2 | Paleogeographic distributions of dolichosaurs according to stage of Cretaceous. (A) Hauterivian (132.9-129.4 My); (B) Barremian (129.4-125.0 My); (C) Albian (113.0-100.5 My); (D) Cenomanian (100.5-93.9 My); (E) Turonian (93.9-89.8 Ma); (F) Coniacian (89.8-86.3 Ma); (G) Santonian (86.3-83.6 Ma); (H) Campanian/Maastrichtian (83.6-66.0 My). A, Adriosaurus sp.; Am, Adriosaurus microbrachis; Ask, Adriosaurus skrbinensis; Asu, Adriosaurus suessi; At, Acteosaurus tommasinii; C, Coniasaurus sp.; Cc, Coniasaurus crassidens; Cg, Coniasaurus gracilodens; Cm, Carentonosaurus mineaui; d, dolichosaur; $\mathrm{DI}$, Dolichosaurus longicollis; Et, Eidolosaurus trauthi; Hg, Haasiasaurus gittelmani; Jt, Judeasaurus tchernovi; Kh, Kaganaias hakusanensis; M, Mesoleptos sp.; Mz, Mesoleptos zendrinii; Pk, Pontosaurus kornhuberi; PI, Pontosaurus lesinensis; Pm, Primitivus manduriensis; Pr, Pontosaurus 'from the reef' - unnamed; p, pythonomorph lizard (because of their proximity to each other, all the localities in France, and the United States are not shown). Paleogeographic maps from Blakey, R., @2016 Colorado Plateau Geosystems Inc., used with permission. 
Jacobs et al., 2005a; Rage, 2013). The flooded continental margins formed widespread shallow seas dotted with islands. This supported the development of extensive patch-reefs, lagoons, and barrier reefs. In Western Europe, from Ireland to Germany, the warmer waters of the Tethys mixed with the cooler waters of the Atlantic in the Anglo-Paris and North Sea Basins, forming a temperate zone (Diedrich, 2010). This caused the deposition of chalks and marls, rather than the limestones that dominate the rest of the Tethyan region (Robinson, 1986; Owen, 1987).

The Western Interior Seaway was an inland sea that split the western from the eastern side of North America, and stretched from the Arctic Ocean to the Gulf of Mexico. It was formed by the subduction and convergence of the Farallon and North American plates (Robinson Roberts and Kirschbaum, 1995). This caused a basin to form down the center of the continent which was subsequently flooded from the north and south beginning in the Barremian-Middle Albian. The two arms connected in the Late Albian, and the seaway persisted until the MidMaastrichtian, close to the end of the Cretaceous (Hattin, 1982; Kauffman and Caldwell, 1993).

\section{Tethys: Adriatic Region}

In the Late Cretaceous, the Adriatic region was a massive shallow marine carbonate platform that supported rudist and coral reefs. For many centuries, the yellowish-gray limestone has been quarried for building material, which produced huge numbers of fossil plants, invertebrates, fish, and-more rarely-lizards (Stur, 1891).

\section{Slovenia}

Komen (or Comen) is located on the Istrian Peninsula. It is one of the richest sites for Late Cretaceous shallow marine squamates, producing both dolichosaurs and aigialosaurs. The Komen limestones are dark gray and thinly laminated mudstone to wackestone. They contain abundant invertebrates, fish, plants, rudists, and squamates, and represent a very shallow, highly restricted shore comprising lagoons separated by rudist reefs (Cavin and Kolar-Jurkovšek, 2000; Jurkovšek and Kolar-Jurkovšek, 2007).

Though most of the outcrops that produced these lizards can no longer be located, the fish and lizard bearing beds around Komen have been dated to the middle to late Cenomanian using fish fossils and other biomarkers such as foraminiferans (Parona, 1926; Langer, 1961; Polšak et al., 1982; Fuček et al., 1990; Jurkovšek and Kolar-Jurkovšek, 2007).

Besides the Lower Chalk of United Kingdom, the Komen beds produced the first described dolichosaurs: Mesoleptos zendrinii (Cornalia, 1852), Acteosaurus tommasinii (von Meyer, 1860), Adriosaurus suessi (Seeley, 1881), Eidolosaurus trauthi (Nopcsa, 1923), Adriosaurus microbrachis (Palci and Caldwell, 2007), and Adriosaurus skrbinensis (Caldwell and Palci, 2010). The same beds have also produced the basal mosasauroids Carsosaurus marchesetti (Kornhuber, 1893) and Komensaurus carrolli (Caldwell and Palci, 2007). The volume of specimens and species from the same locality (likely the Pivor Formation) indicate an unprecedented concentration of small marine squamates sharing this region.

\section{Croatia}

Croatia-Roughly $300 \mathrm{~km}$ south of Komen, on the Dalmatian Coast of Croatia, is the Island of Hvar (Isola di Lesina). On the north side of this island, between the towns of Stari Grad and Jelsa is an outcrop of fossiliferous Late Cenomanian carbonates spanning the late Cenomanian to early Turonian (biostratigraphy; see Radovčić, 1973, 1975; Herak et al., 1976; Sari and Özer, 2009). This outcrop is the most likely origin of a myriad of shallow marine squamates (Herak, 1959; Langer, 1961; Herak et al., 1976). Like the fossils from Komen, the dolichosaurs and aigialosaurs discovered here are among the first described representatives of their respective families. Adriosaurus suessi (Seeley, 1881), Pontosaurus lesinensis (Kornhuber, 1873; Kramberger, 1892), Mesoleptos zendrinii (Cornalia, 1852), a new species of undescribed Pontosaurus (Campbell Mekarski and Caldwell, personal observation), and several indeterminate dolichosaur remains make up the described dolichosaur fanua. Among the basal mosasauroids, the monotypic holotypes of Aigialosaurus dalmaticus, Aigialosaurus bucchichi, and Aigialosaurus novaki originate from Hvar (Kramberger, 1892; Kornhuber, 1901). Interestingly, Hvar has produced the single known specimen of $P$. lesinensis, Pontosaurus sp. nov., A. dalmaticus, A. bucchichi, and A. novaki, indicating a different ecosystem structure than the paleoenvironment at Komen even though the fossiliferous layers containing the lizards are also dated to the late Cenomanian (Starigrad Formation; Marinčić, 1997; Diedrich et al., 2011). The depositional setting at Hvar was a highly restricted shallow marine environment, most likely in very shallow lagoons surrounded by rudist reefs on an inner platform close to the shore (Radovčić et al., 1983; Fuček et al., 1990; Diedrich et al., 2011). The facies containing abundant rudist fossils is also rich in benthic organisms including mussels, clams, worms, echinoids, oysters and other sparsely preserved organisms of various environmental origin including land plants, fishes of the shallow shelf, and cephalopods of the deeper shelf (Radovčić, 1975; Radovčić et al., 1983; Diedrich et al., 2011).

\section{Tethys: Eastern Reaches Kazakhstan}

Far to the east of Komen and Hvar is Kazakhstan, which in the Cenomanian also lay on the northern border of the Tethys. A single isolated vertebra was described from the upper midCenomanian upper phosphatic horizon of the Mangyshlak Plateau (Averianov, 2001). The indeterminate dolichosaur is associated with a diverse assemblage of sharks, cephalopods, gastropods, echinoderms, and bivalves. The depositional environment was shallow marine with terrestrial input and can be correlated to the Anglo-Paris Basin based on ammonites and inoceramid bivalves (Gale et al., 1999).

\section{Tethys: Middle Eastern Region Lebanon}

The 'Fish Beds' of the Sannine Formation, Lebanon are the origin of several taxa of Cenomanian small marine squamates. The Sannine Formation was laid down in a low energy, shallow carbonate platform thought to represent a 
system of lagoons, rudist patch reefs, and small islands (Dal Sasso and Pinna, 1997; Dalla Vecchia et al., 2002). The appropriately named "fish beds" produce mainly teleosts and crustaceans, but also bivalves, plants, and rare tetrapods including turtles, lizards, and limbed snakes (Dal Sasso and Renesto, 1999; Dalla Vecchia et al., 2002). Several Sannine outcrops in Lebanon have produced squamate remains: Nammoura, Hakel, and Hadjula. Al Nammoura (or En Nammoura) is a mid-Cenomanian Lagerstätten located in the Garbour Valley in the north of Lebanon that produced the holotype of Pontosaurus kornhuberi (Dal Sasso and Renesto, 1999; Caldwell and Dal Sasso, 2004; Caldwell, 2006). This specimen is the most complete pythonomorph lizard described to date, preserving the entire skeleton, scalation, and cartilage. This same locality also produced the holotype of the hindlimbed snake Eupodophis (= Podophis) descouensi (Rage and Escuillié, 2000). Dalla Vecchia et al. (2002) proposed that this locality developed in an anoxic, possibly hypersaline lagoon, leading to the stunning preservation of soft tissues. It is dated to the latest middle Cenomanian based on foraminiferan biostratigraphy, the same age or slightly older than the locality at Hakel and Hadjula (Dalla Vecchia et al., 2002). Hakel (or Hâqel) is associated with a small basin on the outer margin of the continental shelf, and has also produced four specimens of Eupodophis descouensi (Rieppel and Head, 2004).

Aphanizocnemus libanensis is a small marine squamate of uncertain affinities from the lower-middle Cenomanian of Lebanon (Dal Sasso and Pinna, 1997; Dal Sasso and Renesto, 1999). The exact locality of its discovery is uncertain, but it is almost certainly from one of the three Sannine outcrops mentioned above.

\section{Palestine}

The 'Ain Yabrud (or 'Ein Jabrud) locality of Palestine is an early to middle Cenomanian outcrop that has produced several small marine squamates. These include the hindlimbed snakes Pachyrhachis and Haasiophis (Caldwell and Lee, 1997; Tchernov et al., 2000), and the pythonomorph lizard Haasiasaurus (= Haasia) gittelmani (Polcyn et al., 1999, 2003). Haasiasaurus was described as a mosasauroid, but may represent a more basal pythonomorph lineage. An articulated specimen of Mesoleptos can also be attributed to this locality (Lee and Scanlon, 2002). The locality is alternatively assigned to the Amminidav Formation (Chalifa, 1985, 1989) or the Bet-Meir Formation (Lee and Caldwell, 1998; Lee and Scanlon, 2002), of the latest early Cenomanian (ammonite dating; Lewy and Raab, 1976). The depositional environment of 'Ain Yabrud is a low energy, shallow marine platform interpreted as a bay close to a river mouth or an interreef lagoon similar to the depositional environment in $\mathrm{Al}$ Nammoura, Hvar, and Komen (Lee and Caldwell, 1998; Polcyn et al., 1999; Jacobs et al., 2005b). The fossiliferous interval preserves terrestrial plants, squamates, turtles, teleost fishes, elasmobranchs, ammonites, bivalves, crustaceans, and echinoderms, often including soft tissue structures (Polcyn et al., 1999).

\section{Palestine and Israel}

The Judean Hills near Jerusalem have produced another basal pythonomorph lizard of uncertain affinities: Judeasaurus tchernovi (Haber and Polcyn, 2005). Lithological analyses indicate that this specimen was deposited in a shallow, lowenergy marine environment with little to no terrigenous input. The most likely origin of this specimen is the midCenomanian Kefar Sha'ul or Bina Formation, part of the Judea Group (biostratigraphy; Lewy, 1989, 1996). The depositional environment was most likely a restricted basin on a continental shelf with input from the open ocean, and was rich in fish and ammonites (Haber and Polcyn, 2005).

\section{North Sea Basin and Anglo-Paris Basins United Kingdom}

In the early late Cenomanian, much of United Kingdom was submerged under the Tethys and the Northern Atlantic, forming a broad continental shelf under a shallow sea which produced the Chalk Group: massive soft chalk deposits interspersed with thinner marl and harder, lithified chalk layers. The soft chalks represent deeper water settings, while the harder chalks and marls are thought to have formed in a shallower environment nearer to shore (Robinson, 1986; Owen, 1987). The fossils of the Chalk are diverse and well-studied. A variety of invertebrate (bivalves, cephalopods, arthropods, sponges, bryozoans, echinoderms) and vertebrate (teleost fishes, sharks, sauropterygians, ichthyopterygians, dinosaurs, and pterosaurs) remains show a relatively complete picture of the relatively shallow, continental shelf ecosystem (Owen, 1842, 1850). Dolichosaur fossils are rarer, and are found only in Chalk outcrops in Sussex and Kent (southeast of United Kingdom). Coniasaurus crassidens and Dolichosaurus longicollis are both represented by multiple fragmentary remains spanning the West Melbury Marly Chalk Formation (lower-middle Cenomanian) and the Zig-zag Chalk Formation (Upper Cenomanian), to the Plenus Marl Member (upper Cenomanian) (Owen, 1850, 1851). This indicates that both species occupied marine shallow water environments in the Cenomanian. Coniasaurus gracilodens is represented by a single specimen from the Zig Zag Chalk Formation (Lower Cenomanian) of Sussex (Caldwell, 1999).

\section{Germany}

Cenomanian Germany sat northeast of the Anglo-Paris Basin, at the southern edge of the North Sea Basin, which was also covered by a shallow sea (Diedrich, 2010). The proximity makes it unsurprising that similar taxa make up the fossil fauna. Fragmentary Coniasaurus crassidens and Dolichosaurus longicollis have been found in Halle/Westphalia in northwest Germany (Diedrich, 1997, 1999) in the Schwarzbunte Wechselfolge Formation which are marked by a series of large ammonite accumulations. Biostratigraphic correlations and isotope anomalies have been used to date this formation and correlate it to sections in United Kingdom, France, and the northern Tethys including the Plenus Marl of United Kingdom (Lehmann, 1999; Diedrich, 2010). Remains of Coniasaurus and Dolichosaurus were recovered from ammonite scour troughs indicating that the lizards may have been using 
the accumulation of large ammonite $(60-80 \mathrm{~cm})$ shells for protection or hunting opportunities (Diedrich, 2010). In between the ammonites, hundreds of marine fossils are reported, including chondrichthyans, cephalopods, gastropods, bivalves, echinoids, asteroids, brachiopods, annelids, and crustaceans. The depositional environment is interpreted as an offshore submarine swell on a rapidly shallowing slope (Diedrich, 1999, 2010).

\section{Atlantic Margin}

\section{France}

Southwest of the Anglo-Paris basin, lying roughly on the border of the Cenomanian Atlantic Ocean and the Tethys Seaway, is the Aquitaine Basin. This basin currently occupies the south west quadrant of modern France, and in the Cenomanian, was overtaken by the transgression of the Atlantic Ocean. Deposits from this western edge of the Aquitaine Basin have produced isolated material (mostly vertebrae) of Carentonosaurus mineaui, a pythonomorph lizard of uncertain affinities (Rage and Néraudeau, 2004). The specimens come from at least two localities in Western France: the lower upper Cenomanian of Île Madame (Charente Maritime), the upper Cenomanian of La Couronne (Charente), and possibly other locations including the lower Cenomanian of Les Renardičres (Charente Maritime), the basal upper Cenomanian of RoulletSaint-Estčphe (Charente), and the upper Cenomanian of Douce Amie (Sarthe). The specimens from Île Madame come from two units, both Cenomanian in age (biostratigraphy; Néraudeau et al., 1997; Rage and Néraudeau, 2004). The majority originate from the 'Dm' unit, a silty limestone corresponding to a deeper marine environment and containing adundant echnoids and cephalopods (Rage and Néraudeau, 2004; Csiki-Sava et al., 2015). The rest of the specimens are from the 'C4ms' unit, a silty unit indicative of very shallow, high-energy marine environment abundant in rudist and stromatoporoid reefal material (Rage and Néraudeau, 2004; Csiki-Sava et al., 2015). Nearby localities with Cenomanian-aged deposits have also produced specimens referred to Simoliophis rochebrunei, a hindlimbed snake (Bardet et al., 2008).

\section{Spain}

The La Cabaña Formation (middle?-late Cenomanian) of Asturias, Spain is a microsite that preserves vertebrate remains of a shallow coastal platform and lagoon with continental input (Vullo et al., 2009). The vertebrate fauna includes fish, turtles, crocodilians, plesiosaurs, dinosaurs, pterosaurs, and marine squamates. The mixture of terrestrial and marine fauna is believed to result from a transgressive lag likely containing reworked remains from older middle Cenomanian deposits (dating based on sequence- and biostratigraphy; Wilmsen, 1997; Vullo et al., 2009; Csiki-Sava et al., 2015). The assemblage of La Cabaña compares favorably to that of Charentes (France), which was also part of the Bay of Biscay (Wilmsen, 1997; Csiki-Sava et al., 2015). Vullo et al. (2009) suggest that the Bay formed an area of endemism during the mid-Cretaceous. Among the endemic taxa supporting this hypothesis is the marine squamate Carentonosaurus (Rage and Néraudeau, 2004). Carentonosaurus is the most abundant tetrapod taxon in Charentes and Asturias, but isolated Coniasaurus-like vertebra and Simoliophis-like vertebra have also been identified (Vullo et al., 2009).

\section{Western Interior Seaway}

The Western Interior Sea was a continental flooding of the foreland basin which runs longitudinally down the center of North America. The basin, which was caused by the uplift of the Rocky Mountains to the west, was inundated from the north by the Arctic Ocean, and from the south by the Atlantic/Tethys. Little to no polar ice, and higher rates of sea floor spreading caused a sea level that was much higher than it was today. This period lasted from the late Albian ( 100 mya) to the late Maastrichtian ( 66 mya) and was marked by multiple transgressive/regressive events (Kauffman and Caldwell, 1993; Robinson Roberts and Kirschbaum, 1995). This shallow epicontinental seaway, along with the Tethys Sea, has the densest concentration of Cretaceous small marine squamates, though most of the occurrences in the Western Interior are assigned to a single genus: Coniasaurus.

\section{United States}

Several Cenomanian formations from the southern United States have produced disarticulated and incomplete remains of the dolichosaur Coniasaurus. The Eagle Ford Group, Greenhorn Formation, Graneros Shale Formation, and Lake Waco Formation all represent marine environments with fragmentary Coniasaurus remains.

The Eagle Ford is the only formation in the Western Interior that has so far produced more than one type of small marine squamate: the dolichosaur Coniasaurus crassidens (Bell et al., 1982; Jacobs et al., 2005a) and the basal mosasauroid Dallasaurus turneri (Bell and Polcyn, 2005). The Eagle Ford spans the early Cenomanian to the latest Turonian, and contacts the Coniacian Austin Chalk (biostratigraphy, correlation, geochemical dating; Denne et al., 2016). The only Cenomanian marine squamate represented is Coniasaurus, which is found in the Tarrant and Britton Formations of Texas (Bell et al., 1982; Jacobs et al., 2005a). The paleoenvironment was shallow, low-energy marine in association with a river delta (Kauffman and Caldwell, 1993; Denne et al., 2016).

The Greenhorn Formation is extensively exposed throughout the central states: Wyoming, South Dakota, Colorado, Nebraska, Kansas, and New Mexico. The Formation spans the mid Cenomanian to mid Turonian (biostratigraphy; Hattin, 1975; Von Loh and Bell, 1998). The higher beds yield derived marine squamates (mosasaurs), while the lower beds (Orman Lake Member) produce Coniasaurus until just below the CenomanianTuronian boundary in Kansas (Liggett et al., 2005), Colorado (Shimada et al., 2006), and South Dakota (Von Loh and Bell, 1998). Like the Eagle Ford, the depositional environment is offshore, deep-water, low-energy marine (Von Loh and Bell, 1998). The abundance of Coniasaurus material from this Formation is particularly notable; for example, Shimada et al. (2006) recovered almost 400 isolated teeth from a deposit in southeastern Colorado.

The middle-Cenomanian Graneros Shale Formation contacts the base of the Greenhorn Formation in Kansas. The depositional 
environment was shallower, and higher energy than the Greenhorn Formation. Coniasaurus remains (including teeth and a partial maxilla) have been found here, but only at the top of the formation, at the contact between the Graneros Shale and Greenhorn (Liggett et al., 2005).

Unlike the previous formations bearing Coniasaurus fossils, the mid-Cenomanian-Early Turonian (dated biostratigraphically, geochemically) Lake Waco Formation of Texas is higher energy, with consistent current action (Denne et al., 2016). Plesiosaur, chondrichthyan, ammonite, and inoceramid fossils have been recovered from its strata (Thurmond, 1968; Denne et al., 2016). The Bluebonnet Member had a relatively shallow depositional environment, likely a foreshore or bar with abundant plant fossils likely representing marsh-growing reeds (Silver, 1963).

\section{Canada}

Cumbaa et al. (2006), in a description of a Cenomanian bonebed fauna from Saskatchewan, Canada, report fragmentary vertebral and dental elements that they tentatively identified as ?Coniasaurus crassidens. The locality at the Pasquia Hills is a middle-Cenomanian deposit on the northernmost upland of the Manitoba Escarpment, part of the Belle Fourche Member of the Ashville Formation which is dated using biostratigraphic and regional chronostratigraphic (bentonite) markers (Cumbaa et al., 2006). If these remains do represent a coniasaur, it would be the first and only occurrence from Canada. However, Shimada and Ystesund (2007) express their doubt that the specimens represent a dolichosaur, citing personal communications with the original authors. The bonebed also preserves a wide variety of taxa, including chondrichthyans and actinopterygians of several orders, turtles, sauropterygians, and a surprising diversity of birds (Cumbaa et al., 2006). The bonebed appears to have been deposited in shallow, inshore marine waters with a strong tidal influence and may have represented a lagoonal environment (Cumbaa et al., 2006).

\section{Turonian (Upper Cretaceous); Figure 2E}

Though the Turonian is nowhere near as rich in dolichosaur species or density as the Cenomanian, it does reflect a wider geographical distribution (Europe, North America, and South America). The drop in diversity could be attributed to sampling bias, or to an extinction event: the Cenomanian-Turonian Boundary Event (CTBE), which caused significant biotic and geologic changes between these two time periods (Lamolda et al., 1994; Caldwell and Cooper, 1999).

Other marine squamates achieve a broader diversity and distribution during this time. Limbed snakes, which were exclusively known from Northern and Southern margins of the Mediterranean Tethys, became known intercontinentally in the Turonian (Gardner and Cifelli, 1999; Rage and Werner, 1999; Caldwell and Albino, 2001). Mosasauroids, also exclusively known from Europe in the Cenomanian, increase in size and distribution and by the mid-Turonian could be found in Africa, Europe, and North and South America (Von Loh and Bell, 1998; Bardet et al., 2003, 2008; Buchy et al., 2005; Schulp et al., 2008; Smith and Buchy, 2008; Longrich, 2016).

\section{Colombia}

The Villeta Group near Yaguará, Colombia is an AptianConiacian deposit which contains the La Frontera Formation; a Turonian deposit (based on biostratigraphy) of laminated limestones with well preserved vertebrate remains (Blanco et al., 2004; García Gonzalez et al., 2009). The majority comprised fish, but marine squamates include indeterminate 'varanoid' and 'pythonomorph' lizard remains, and the basal mosasauroid Yaguarasaurus colombianus (Páramo-Fonseca, 1994, 1997). The Turonian of Colombia represented a maximal transgression flooding the plains of Colombia to the Andes. The depositional environment at Yaguará was shallow, low-energy, and anoxic, likely deposited in an open marine platform to submarine fan setting (Blanco et al., 2004).

\section{Mexico}

The early Turonian limestones at Vallecillo, northeast Mexico are part of the Agua Neuva Formation (Buchy et al., 2005) and are dated based on biostratigraphy (Blanco et al., 2001). The Formation does not typically produce macrofossils, except near Vallecillo, which corresponds to a low-energy, outer shelf environment with localized anoxic episodes (Blanco et al., 2001). These restricted preservational conditions allowed a diverse vertebrate fauna-including marine turtles, fishes, sauropterygians, and squamates-to be preserved complete and often with soft tissue impressions and gastric contents (Blanco-Piñón et al., 2002). This is the state of preservation of Vallecillosaurus donrobertoi (Smith and Buchy, 2008). Though this animal is described as an aigialosaur, the designation is based on caudal neural spine length. Otherwise, the incompleteness of the specimen (pelvis, hind limbs, and anterior caudals) and the lack of diagnostic elements allow that this specimen could be an aigialosaur or a dolichosaur.

\section{United States}

Several formations in the United States preserve Turonianaged Coniasaurus material. These include groups that span the Cenomanian-Santonian, indicating a long history of Coniasaurus occupation in the Western Interior Basin.

As mentioned above, the Eagle Ford (spanning the early Cenomanian to latest Turonian of Texas) is the only formation in the Western Interior to produce more than one small marine squamate: the dolichosaur Coniasaurus crassidens (Bell et al., 1982; Jacobs et al., 2005a) and the basal mosasauroid Dallasaurus turneri (Bell and Polcyn, 2005). At the top of the Group is the Arcadia Park Formation, which contacts the Austin Chalk (Coniacian). Like the Britton Formation, the Arcadia Park Shale was deposited on a shallow marine shelf in association with a freshwater delta (Denne et al., 2016). The fauna is represented by the mosasaur Russellosaurus (Bell et al., 1982; Jacobs et al., 2005a; Polcyn and Bell, 2005), chondrichthyans, osteichthyans, ammonites, clams, oysters, and foraminifera (Moreman, 1942; Denne et al., 2016).

The Boquillas Formation (upper middle Turonian, southeastern Texas) is correlated with the Britton and Arcadia Park Formations of the Eagle Ford Group in Central Texas (Udden, 1907; Huffman, 1960) and has produced 
Coniasaurus material, as well as indeterminate Mosasauroidea and Russellosaurina material, sharks, and bony fishes (Cicimurri and Bell, 1996). Invertebrate fossils found in the formation include ammonites, crinoids, clams, urchins, and oysters (Denne et al., 2016). The Ernst Member, which preserves the fossil lizards, was deposited on the warm, shallow open shelf of a transgressive sea (Huffman, 1960; Cicimurri and Bell, 1996).

The Carlile Shale (which overlies the Greenhorn Formation; Shimada and Bell, 2006) of South Dakota and Kansas has also yielded isolated Coniasaurus remains (Bell and Polcyn, 1996; Shimada and Ystesund, 2007). The Turner Sandy Member of South Dakota (Bell and Polcyn, 1996), and the Fairport Chalk Member of Kansas (Everhart and Darnell, 2004; Shimada and Ystesund, 2007) are the source of the coniasaur material. The Shales were deposited in a very shallow marine environment close to the shoreline and are Upper Turonian in age (biostratigraphy; Hattin, 1982). The vertebrate fauna includes cartilaginous fishes, bony fishes, turtles, mosasaurs, plesiosaurs, crocodyliforms, and a bird (Shimada and Ystesund, 2007).

\section{France}

An isolated vertebra of an indeterminate 'dolichosaurid' was described by Rage (1989). The vertebra originates from SainteMaure, Touraine, in western France. It is derived from the Saumur Tuffeau, dated to the middle Turonian (based on ammonite dating), and representing relatively shallow outer to inner shelf environments (Rage, 1989; Bardet et al., 1998). Isolated aigialosaurid and mosasaurid vertebrae, and remains from a cheloniid turtle have also been found in these deposits (Bardet et al., 1998). The specimen was later compared more favorably to indeterminate pythonomorph vertebrae from France (Houssaye, 2010), thus altering its status to Pythonomorpha incertae sedis.

A set of 25 isolated vertebrae were discovered in a quarry south of Le Paluau, Indre-et-Loire, western France corresponding to the stratigraphical unit 'Falun de Continvoir' (Houssaye, 2010): a shallow marine environment rich in bryozoan and bivalve fragment of late Turonian age (Alcaydé, 1975). The unique shape of the vertebrae was used to suggest that these disarticulated elements may represent a new pythonomorph taxon, though due to a lack of clearly distinctive characters, the taxon was not named (Houssaye, 2010). The different size classes recovered suggest that several individuals are represented.

\section{Coniacian (Upper Cretaceous); Figure 2F United States}

Shimada et al. (2007) described what appears to be an unusually large dolichosaurid tooth similar in anatomy to Coniasaurus crassidens. The find originates from an upper Coniacian unit (based on lithographic marker units) in the Smoky Hill Chalk Member of the Niobrara Chalk Formation in Trego County, Kansas. The Smoky Hill Chalk was deposited hundreds of kilometers from shore under warm (temperate to subtropical), calm, slightly hypoxic conditions (Hattin, 1982). This horizon is rich in marine vertebrate fossils, including cartilaginous and bony fish, plesiosaurs, mosasaurs, and marine turtles (see Shimada et al., 2007, Table 1). Due to the isolated nature of the tooth, it is impossible to tell if it is indeed a dolichosaur, but if it is, it would represent the largest dolichosaur described (based on tooth scaling; Shimada et al., 2007). It would also represent the only Coniacian record of dolichosaurs worldwide.

\section{Santonian (Upper Cretaceous); Figure 2G United States}

The Coniacian-aged Coniasaurus discovery of Shimada et al. (2007) is not the youngest reported Coniasaurus. Another occurrence was described by Shimada and Bell (2006) from the same Member and Formation: the Smoky Hill Member of the Niobrara Chalk (western Kansas). A single isolated vertebra diagnosed as Coniasaurus sp. was recovered from layers established as middle Santonian in age based on lithostratigraphic markers and biostratigraphy (Kauffman and Caldwell, 1993). Mentioned above, the Smoky Hill Member represents the Coniacian-Campanian shallow carbonate platform flooded by the Western Interior Sea (Shimada and Bell, 2006). Unlike most other Coniasaurus-bearing units, the Formation was deposited a few hundred kilometers from shore. Within the same horizon are other marine reptiles including plesiosaurs, marine turtles, and mosasaurs, as well as non-marine reptiles including nodosaurid dinosaurs, pterosaurs, and birds (Everhart, 2005; Shimada and Bell, 2006; Shimada and Ystesund, 2007).

\section{Spain}

A collection of 10 isolated vertebrae and 16 teeth was discovered in the Calvero de la Higuera complex, near the village of Pinilla del Valle, northwest of Madrid, Spain (Hontecillas et al., 2015). The complex is a series of cave deposits known for Pleistocene mammals and hominids. The 26 specimens originate from karstic structures formed from Santonian aged marine marls, sandstones, and dolomites. During the Quaternary, the area was karstified, and eventually infilled with fluvial sediments and with sediments formed during the degradation of the karst structures (Peréz-González et al., 2010). It is these reworked Quaternary sediments which produce both Cretaceous and Quaternary vertebrate remains, including the squamate material described. The reptile remains (which are found in association with the teeth of chondrichthyans and osteichthyans) are within Late Cretaceous dolomites and sandstones with dolomitic cement (Peréz-González et al., 2010). Based on correlation with other Late Cretaceous outcrops in the surrounding area, they are assigned to the Santonian (Alonso, 1981; Hontecillas et al., 2015). The squamate material was assigned to Carentonosaurus mineaui, which greatly extends the range of this genus, which was previously only known from the Cenomanian.

\section{Campanian-Maastrichtian (Upper Cretaceous); Figure 2H \\ Argentina}

Albino (2000) reported on an isolated vertebra from the La Colonia Formation, on the southeastern margin of the Somún Curá Plateau, Argentina. The age of this Formation is not well established, but based on micropaleontological data and stratigraphic relations, it seems to span the CampanianMaastrichtian (Pascual et al., 2000). The deposit was suggested 
to be an estuary, coastal plain, or tidal flat, since marine, fluvial, and terrestrial taxa are all present (Pascual et al., 2000; Gasparini et al., 2015). Among these was a single vertebra that Albino (2000) assigned to 'Serpentes incertae sedis.' However, this assignment has since been questioned, with Scanlon and Hocknull (2008) comparing it more favorably to a dolichosaur.

\section{Spain}

The "Lo Hueco" site of Cuenca, central Spain, is a late Campanian-early Maastrichtian site dated based on relative stratigraphic position and paleontological content (PeredaSuberbiola et al., 2002; Barroso-Barcenilla et al., 2009). It has a diverse vertebrate fauna including terrestrial squamates, turtles, crocodiles, fishes, pterosaurs, and dinosaurs; notably an abundance of titanosaurs (Barroso-Barcenilla et al., 2009). This is in addition to a diverse plant flora, and rarer invertebrates including molluscs and gastropods. The site is located in the upper part of the "Margas, Arcillas y Yesos de Villalba de la Sierra" Formation, and likely represents a muddy flood plain near the coast, swampy, crossed by sandy delta channels, and subjected to both brackish and fresh water influence (BarrosoBarcenilla et al., 2009; Csiki-Sava et al., 2015). Two isolated vertebrae were identified as a novel type of pythonomorph lizard, though the taxon was left unnamed due to the minimal amount of represented material (Houssaye et al., 2013).

\section{France}

Another isolated vertebra was described from the late Maastrichtian Cassagnau locality (Auzas Marls Formation) of Haute-Garonne, south-west France (Laurent et al., 2002). The authors mention that the undescribed form is known from Campanian and Early Maastrichtian localities in Southern France, in addition to the Late Maastrichtian locality (dated using micropaleontological evidence) described in the paper (Laurent et al., 1999, 2002). The vertebra is incomplete, and as mentioned by Houssaye et al. (2013), it cannot be definitively determined whether it represents a pythonomorph or not. The Late Maastrichtian locality at Cassagnau preserves terrestrial and marine vertebrates including fishes, amphibians, chelonians, crocodiles, dinosaurs, and birds, as well as bivalves, ostracods, and gastropods (Laurent et al., 2002). The depositional environment was brackish, and marginally marine to estuarine (Bilotte, 1980; Lepicard, 1985).

\section{Italy}

Primitivus manduriensis is a newly reported pythonomorph lizard originating from upper Campanian-lower Maastrichtian deposits in Apulia, Italy (Paparella et al., 2018). It is the first record of dolichosaurs from the southern Italian Carbonate Platform, and the youngest reliable occurrence of dolichosaurs worldwide (dating based on nanofossils; Sorbini, 1978; Medizza and Sorbini, 1980). From the Late Jurassic to the Late Cretaceous, the Apulian Platform was a shallow sea abundant in fish and small invertebrates, and containing an archipelago-like arrangement of small islands (Citton et al., 2015). The locality from which the fossil was recovered (near Nardò, Lecce, Puglia) is known for its fossiliferous limestones, which were deposited in a shallow inner lagoon on the Apulian Platform (Bossio et al., 2006). The lithology, lack of microfossils, and lack of trace fossils associated with the specimen suggest that it was deposited in warm, anoxic to dysoxic waters (Paparella et al., 2018) in potentially a sabkha-like environment similar to that described from Hvar, Croatia by Diedrich et al. (2011).

\section{DISCUSSION}

\section{Oceanographic Context}

The radiation of aquatic squamates (including dolichosaurs) is obviously very closely tied to the seaways and oceans they were colonizing. The beginning of the Cretaceous ( $\sim 145$ mya $)$ is roughly 55 million years after the break up of Pangea, and about 35 my after Gondwana started to separate. The continents were still relatively close together (or connected), global sea levels were relatively low, and the Atlantic was only just maturing into an ocean and beginning to form between South America and southern Africa (Haq et al., 1988; Polcyn et al., 1999; Blakey, 2008; Bardet et al., 2014; Scotese, 2014; Csiki-Sava et al., 2015). The earliest Cretaceous represented a greenhouse period, with high global $\mathrm{CO}_{2}$ concentrations and ocean temperatures exceeding $30^{\circ} \mathrm{C}$ in the tropics (Littler et al., 2011). Cold seasurface temperatures and a global anoxic event dominated the Aptian-early Albian, until increased oceanic crust production and hydrothermal activity through the Albian-early Turonian drove a long-term warming trend caused by $\mathrm{CO}_{2}$, and a global eustatic sea level rise (Haq et al., 1988; Clarke and Jenkyns, 1999; Davey and Jenkyns, 1999; Leckie et al., 2002; Jenkyns et al., 2012; Csiki-Sava et al., 2015). The resulting changes in ocean circulation, oceanic stratification, and nutrient partitioning lead to a reorganization of planktonic communities that subsequently caused widespread carbonate deposition in the Late Cretaceous (Leckie et al., 2002). These conditions drove the development of extensive foraminiferan chalk deposits in temperate waters (e.g., the Anglo-Paris Basin and the Western Interior Sea) and of extensive rudistid carbonate platforms in more tropical waters (e.g., Caribbean Tethys and Mediterranean Tethys) (Fuček et al., 1991; Davey and Jenkyns, 1999).

By the mid-Cretaceous, the separation of Gondwana was nearly complete. The rapid spreading of the seafloor and the fragmentation of the continents resulted in shallow epicontinental seas bordering many of the major landmasses that acted as corridors between larger water bodies such as the Tethys, Atlantic, and Pacific (see Bardet et al., 2014; Csiki-Sava et al., 2015 for discussion). In Europe, the complex tectonics created a very dynamic archipelago within the Tethys, unlike any other ecosystem of the time. Blocks of continental crust moving into the spreading area of the Tethys created a series of moving and fluctuating islands that altered population dynamics and geological features in their wake (Csiki-Sava et al., 2015). This unique region formed the basis of many unique faunas and was arguably the driving force behind many distinctive radiations (Bardet et al., 2008; Bardet, 2012; Csiki-Sava et al., 2015).

Reconstruction of Cenomanian current patterns shows a circumglobal current flowed westward through the Tethys 
Seaway and across the Atlantic, forming the 'SuperTethys' (Föllmi and Delamette, 1991; Caldwell and Cooper, 1999). This current is thought to be the primary method of dispersal of certain invertebrate taxa. For example, bivalves go through a planktonic stage, during which time their larvae are free floating and subject to dispersal along ocean currents. Rudist bivalves are known from the Lower Cretaceous (BerriasianValanginian) of the European Tethys but are not recorded in the Caribbean region of the SuperTethys until the Barremian (Johnson and Kauffman, 1990). This dispersal is thought to have been a result of the westward prevailing current carrying the rudist larvae across the Atlantic. This current is one of the factors believed to have facilitated the explosive radiation of rudist reefs that replaced coral-algal paleocommunities during the Barremian-Cenomanian (Johnson and Kauffman, 1990). In addition to rudist-dominated communities being ubiquitous throughout the SuperTethys, invertebrate faunas from the midCretaceous of Australia and New Zealand have also been shown to correspond to European faunas, implying an unrestricted migration route between these two ecosystems during or before the Cenomanian which would have been accessible to dolichosaurs (Stilwell and Henderson, 2002).

The mid-Turonian represents a maximum transgression, with the highest water levels of any time during the Cretaceous (Haq et al., 1988; Davey and Jenkyns, 1999). After the mid-Turonian, mid-Cretaceous sea levels and temperatures drop (Clarke and Jenkyns, 1999; Jenkyns et al., 2004). Even though cyclic transgressions continued throughout the Late Cretaceous (early Turonian, early Coniacian, middle Santonian, late Campanian; Hancock and Kauffman, 1979), there was an overall trend toward lower sea levels. This period also represents the closing of the Tethys: the center of dolichosaur diversity and evolution. As the Atlantic spread and Africa rotated, several microcontinents (Central Turkey, Western Iran, Apulia) drifted northward (Polcyn et al., 1999; Blakey, 2008). The eventual result was the closing of the Tethys, the formation of the Alps, and the assimilation of southern Europe. Thus, lower sea levels, tectonic activity, fewer carbonate shelves, and lower sea surface temperatures likely negatively influenced the evolution and dispersion of dolichosaurs during the latest Cretaceous and could have been a key factor in their extinction.

\section{Paleoenvironment}

Dolichosaurs, though widespread across the world (on every continent except Africa and Antarctica), were primarily distributed within a paleolatitudinal belt between $25^{\circ} \mathrm{N}$ and $50^{\circ} \mathrm{N}$. Within this belt, three major seaways have produced the majority of dolichosaur records: the southern Western Interior Sea, the northern Tethys, and the eastern margin of the Atlantic where it meets the Tethys. No dolichosaur remains have been found north of this paleolatitudinal belt. The southernmost occurrences are isolated remains from Colombia $\left(\sim 5^{\circ} \mathrm{N}\right)$, Argentina $\left(\sim 40^{\circ} \mathrm{S}\right)$, and Australia $\left(\sim 45^{\circ} \mathrm{S}\right)$. Within these paleolatitudes, dolichosaurs are found in a range of depositional environments: from freshwater and marine deposits (though the vast majority are marine) representing tidal flats, lagoons, sabhkas, swamps, reefs, deltas, basins, and open shelf.
Their paleoenvironments were generally warm, but still ranged from the more temperate chalks of United Kingdom to the more tropical limestones from southern Europe (Polšak and Leskovšek, 1975). Assuming that the depositional environments reflect ecological occurrence, this indicates a wide range of ecological niches within relatively shallow, warm water. This pattern agrees with hypothesized paleobiological niche of dolichosaurs as shallow, warm water, marine ambush predators (Caldwell, 1999, 2000, 2006; Lee and Caldwell, 2000; Pierce and Caldwell, 2004; Caldwell and Palci, 2010). Optimal preservation seems to have taken place not on the reefs themselves, but in intra-reef lagoons with localized anoxic conditions (Radovčić et al., 1983; Diedrich et al., 2011).

It has been suggested that, like similarly sized modern marine reptiles, dolichosaurs may have been subject to thermophysiological constraints (due to small body size) that limited their habitats to water between $20^{\circ}$ and $30^{\circ} \mathrm{C}$ (Jacobs et al., 2005b). For example, in the Western Interior Sea, Coniasaurus-bearing rocks were deposited in waters ranging from 20 to $30^{\circ} \mathrm{C}$, which corresponds well to the temperature range inhabited by modern marine squamates: sea snakes and the marine iguana (Jacobs et al., 2005a). The warm waters of the mid-Cretaceous (late Albian-early Campanian), which are estimated to have reached $20^{\circ} \mathrm{C}$ in the Arctic (Jenkyns et al., 2004) and $35^{\circ} \mathrm{C}$ equatorially (Norris et al., 2002), would have provided little barrier to migration, even into high latitudes. Selection for slightly warmer water could explain why dolichosaurs seem to be restricted to the paleolatitudinal belt between $25^{\circ} \mathrm{N}$ and $50^{\circ} \mathrm{N}$.

In comparison to other Cretaceous marine squamates, dolichosaurs occupy a broader range of paleoenvironments than limbed snakes, which exclusively occupied the carbonate platforms of the Mediterranean Tethys, especially the more tropical southern margin (Rage and Escuillié, 2003; Bardet et al., 2008). Spatially, however, dolichosaurs are less diverse than mosasauroids. Though the smaller aigialosaurs were mostly restricted to the Tethys and Western Interior Seaway, derived mosasaurids were cosmopolitan in their distribution, with a diverse range of habitats including open ocean, near shore, and even freshwater environments (Bardet et al., 2008; Makádi et al., 2012). This supports the hypothesis that dolichosaurs may have been thermophysiologically constrained, as the larger mosasaurs (by virtue of their size), would likely have been less restricted by water temperature.

\section{Origin, Radiation, Extinction}

Robust hypotheses on the spatiotemporal and environmental origin of dolichosaurs have been precluded by the poor fossil record in the Early Cretaceous and in fact in the Upper Jurassic as well. Three records (an articulated specimen and two isolated vertebrae) from three distant localities on three continents (Japan, Spain, and Australia; Rage and Richter, 1994; Evans et al., 2006; Scanlon and Hocknull, 2008) have justifiably prohibited much spatiotemporal analysis. These early occurrences are equally confounding because all three come from freshwater deposits, while most Cenomanian-Campanian dolichosaurs originate from marine beds. Another confounding factor is the origin of ophidians, the closest sister group of 
the dolichosaurs. The oldest known snake is Middle Jurassic in age (Caldwell et al., 2015), while dolichosaurs are first documented from Lower Cretaceous sediments. This means that if dolichosaurs do represent a paraphyletic assemblage from which the monophyletic Ophidia originated, then the origin of non-ophidian ophidiomorphs happened during the Middle Jurassic, or perhaps even earlier (Caldwell, 2019). Currently, two models have been proposed for the origin of non-ophidian ophidiomorphs: a Tethyan origin, or a Western Pacific origin, though the possibility of multiple independent lineages cannot yet be ruled out, and thus multiple ancient areas of origin (see for example: Evans et al., 2006; Bardet et al., 2008; Scanlon and Hocknull, 2008). For the sake of argument, we examine the two existing origin models based on our assemblage of all existing data.

\section{Tethyan Origin}

Early pythonomorph diversity is highest in the Western Tethys (southern Europe and the Middle East; Bardet et al., 2008). Therefore, the most parsimonious explanation is that this area was the area of origin for all pythonomorphs, including dolichosaurs, sometime during the Jurassic. Shallow carbonate shelves bordering southern Laurasia and eastern Gondwana from the Berriasian to the Barremian (Lower Cretaceous) would have provided an easy route by which small pythonomorph lizards, adapted to shallow marine environments, could have spread to Japan and Australia by the Early Cretaceous (Kear et al., 2017). These shallow epicontinental shelves kept the animals comfortably within their tropical to temperate belt, and likely provided very little obstruction to dispersal. Once established on coastlines bordering the Pacific, independent populations could have adapted to freshwater environments several times, eventually colonizing the widely distant river and lake deposits. High sea surface temperatures in the Southern Hemisphere in the late Albian could explain the presence of a dolichosaur in Australia, at the highest latitudinal occurrence of any platynotan during the mid-Cretaceous (Jacobs et al., 2005a; Scanlon and Hocknull, 2008). A native dolichosaur population remaining within the Tethys would have formed the basis of the explosive radiation in the Cenomanian. An Early Jurassic, circa-Tethyan origin of the Ophidiomorpha fits well with these findings, and time-wise would accommodate the occurrence of dolichosaurs many hundreds of kilometers away in Japan and Australia.

Similar models for the origin and distribution of other marine tetrapods, such as mosasaurs, support this hypothesis. Prior to the Turonian, mosasauroids (aigialosaurs) are exclusively found in Tethyan deposits from the Mediterranean and the Middle East (Kramberger, 1892; Kornhuber, 1893, 1901; Polcyn et al., 1999; Dutchak and Caldwell, 2006, 2009; Caldwell and Palci, 2007). After an initial westward dispersal to the Western Interior, they quickly developed more specialized adaptations to the marine environment, dispersed globally, and by the mid-Turonian could be found in the Western Interior, the Atlantic, the Tethys, and possibly the Pacific; and by the end of the Turonian, they were essentially cosmopolitan (Bardet et al., 2003, 2008, 2014; Kear et al., 2005; Houssaye and Bardet, 2013). Since aigialosaurs are here interpreted to have had similar paleoecological niches as dolichosaurs, it stands to reason that their distribution would have followed a similar route.

The absence of dolichosaur material in Tethyan deposits prior to the Cenomanian is the primary challenge to this model. The lack of pythonomorph lizards in the Early Cretaceous could be simply explained by a sampling bias caused by the limited exposure of certain ages (Csiki-Sava et al., 2015).

\section{Western Pacific Origin}

The alternative to the Tethyan origin model, is that of a Western Pacific origin. Evans et al. (2006) hypothesized that the ancestral pythonomorph lizards initially colonized freshwater, before adapting to brackish and finally marine environments. They suggest that Kaganaias could represent an early, freshwater stage of that transition, implying that the high concentration of Cenomanian Tethyan dolichosaurs represents a lineage already well established and adapted to the marine environment, having successfully radiated and migrated from their freshwater origins.

Following an initial invasion of the marine environment somewhere along the Western Pacific margin, a rapid radiation in the upper Early Cretaceous would have had basal dolichosaurs expanding their range westwards to the Tethys, or eastwards across North America and into Europe while making multiple independent freshwater reinvasions in Australia and Spain. The North American radiation would have likely happened later, in the early Late Cretaceous. Several terrestrial groups-including squamates (e.g., Nydam et al., 2007) - may have followed this migration pattern in the Late Cretaceous, indicating that such a model is certainly within the realm of possibility (see Csiki-Sava et al., 2015 for discussion).

\section{Late Cretaceous Radiations and Extinctions}

As of the Cenomanian, the distribution pattern of dolichosaurs appears relatively straightforward. In the early to midCenomanian, a rapid radiation and diversification within the European Tethys is reflected in the diversity of the fossil record. A parallel radiation likely had Coniasaurus-like forms expanding their range westward across the Tethys, crossing the northern margin of the narrow Atlantic, and radiating throughout the interior of North America during the maximum Cretaceous transgression (Jacobs et al., 2005a). The speed of their migration was such that by the middle Cenomanian, they were well established up and down the Western Interior Seaway. The speed and route of their migration closely matches that of the rudist bivalves, that spread westward through the SuperTethys during the Barremian-Cenomanian (Johnson and Kauffman, 1990; Caldwell and Cooper, 1999). Whereas the bivalve larvae would have floated on prevailing currents, it is more likely that the actively swimming dolichosaurs followed either the southern coastline of the Atlantic along western Africa to South America, or the northern coastline through the Baltics and along eastern North America (Caldwell and Cooper, 1999). The migration pattern also compares well with that proposed for the Turonian distribution of russellosaurines and aigialosaurs (Bell, 1997; Bardet et al., 2008; Kear et al., 2013). 
Interestingly, after the Cenomanian, there is no record of dolichosaurs in Asia or Australasia, both of which had possible pre-Cenomanian records. Several hypotheses exist to explain this: first, that these tentative, fragmentary records are not dolichosaurs at all. Second, it is possible that dolichosaur populations did exist on these continents but have not been found due to sampling bias and their relative rarity. Finally, that these animals suffered from the mass-extinction event associated with the end of the Cenomanian, the CenomanianTuronian boundary event (CTBE; Lamolda et al., 1994). The CTBE was a short $(\sim 250 \mathrm{ka})$ global oceanic anoxic event possibly linked to rapid oceanic plateau formation and/or increased rates of ridge crest volcanism (Lamolda et al., 1994; Kerr, 1998; Davey and Jenkyns, 1999; Leckie et al., 2002; Wan et al., 2003; Turgeon and Creaser, 2008). The event lead to an extensive faunal turnover, especially in the marine realm where it caused the extinction of roughly $27 \%$ of marine invertebrates (Turgeon and Creaser, 2008), and an estimated $90 \%$ of benthic foraminiferans, and $50-70 \%$ of planktonic foraminiferans (Wang et al., 2001). These invertebrate extinctions were particularly important since these taxa were the builders of the carbonate platforms that formed the basis of the dolichosaurs' ecosystems. The CTBE, which restructured marine ecosystems globally, could easily have affected dolichosaur ecosystems and thus populations, causing an extinction or near-extinction of dolichosaurs outside of their population centers: the Tethys and the Western Interior. The radiation of mosasauroids in the Tethys during the Turonian (Bardet et al., 2008; Kear et al., 2013) likely exacerbated the situation, possibly putting competition and predation pressures on any surviving dolichosaur populations.

More surprising is the absence of any dolichosaurs in the Eastern Tethys after the CTBE, which had been the center of known dolichosaur diversity in the Cenomanian. This absence is likely an artifact of collection bias combined with the rarity of these fossils. However, it is also possible that the Eastern European dolichosaurs suffered extinction associated with the CTBE. They were living and foraging within the extensive carbonate platforms that were eventually submerged below the euphotic zone and inundated by anoxic water during the transgression of the paleo-seaways (Jenkyns, 1991; Gušić and Jelaska, 1993). In Europe and the Middle East, dolichosaurs rarely appear in the fossil record after the $\mathrm{CTBE}$, and related marine squamates, such as aigialosaurs and limbed snakes (i.e., Pachyrhachis) that were occupying a similar ecological niche, also disappear from the fossil record during this period. The combination of the CTBE and the Turonian radiation of mosasauroids could explain why from the Turonian-Santonian, the only records of dolichosaurs are from the Eastern Atlantic Margin/Western Tethys and the Americas (see Polcyn et al., 2014, Figures 1, 3).

The Turonian through Santonian has a sparse though consistent record of dolichosaurs from the Western Interior and Western Tethys, indicating that though these animals persisted, they generally remained a small part of the fauna in their established biogeographic centers. A peak transgression or maximum flooding during the mid-Turonian
(Davey and Jenkyns, 1999) could have facilitated a possible South American radiation represented by two occurrences from South America. This first, indeterminate pythonomorph remains from Colombia in the Turonian hint at the possibility of a southward migration starting from the Western Interior, moving down along the island system that was Central America, to the shallow epicontinental sea that covered much of the northern half of South America in the mid-Turonian. A second possible occurrence, a single vertebra from Argentina, would imply the continuation of the southward radiation, which reached the southern coast of South America by the Campanian-Maastrichtian.

A recently described pythonomorph Primitivus manduriensis from Apulia, Italy in the Campanian-Maastrichtian (Paparella et al., 2018) implies that even though the diversity of these animals decreased into the Late Cretaceous, they continued to persist along with the more diverse lineages of Late Cretaceous aquatic reptiles including mosasaurs and sauropterygians. The Maastrichtian finds of Italy and France [see section CampanianMaastrichtian (Upper Cretaceous); Figure $\mathbf{2 H}$ ] are the youngest records of non-ophidian ophidiomorphs, implicating the End Cretaceous Mass Extinction as the event that caused the extinction of this group.

\section{Species Distributions and Endemism}

The internal relationships of dolichosaurs are not well resolved, therefore it is difficult to discuss the distribution patterns of separate lineages. However, some interesting patterns do emerge surrounding some distinct paleocommunities.

In the late Cenomanian of Europe, four distinct dolichosaur communities appear to exist despite the fact that the Mediterranean Tethys was continuous with the Northern and Western Tethys regions, and the Atlantic ocean. The most diverse dolichosaur fauna is in the Adriatic region, with multiple genera from Slovenia and Croatia (Calligaris, 1988; Bardet et al., 2008). A second, Middle Eastern fauna appears to have some unique genera such as Judeasaurus and Haasiasaursu, but also appears to have some crossover with the Adriatic region, as both faunas have produced Mesoleptos and Pontosaurus fossils. The Anglo-Paris basin has produced abundant fragmentary Coniasaurus and Dolichosaurus fossils originating from the Northern Tethys margin, but which do not appear in the southern or eastern Tethys. Finally, Carentonosaurus seems to be endemic to the Bay of Biscany/Charentes region at the Eastern margin of the Atlantic. The spatial distribution of these marine lizards must have been impacted by their paleoenvironment and paleoclimate. Climatically, it seems that Coniasaurus and Dolichosaurus must have been adapted to the more temperate climate of the Northern Tethys margin, while the Middle Eastern and Adriatic faunas were better suited for warmer, more tropical areas on the southern Tethys. Environmentally, Carentonosaurus seems to have been the only dolichosaur adapted to the Atlantic coastal terrigenous landscape of the Bay of Biscay. The broad carbonate platforms of the Adriatic and Middle East supported the highest diversity, while the cooler chalk deposits of the Anglo-Paris basin were intermediate. 
In contrast to most dolichosaur species, specimens attributed to Coniasaurus are more pandemic: being spatially diverse and numerous. Coniasaurus crassidens is recognized from the Cenomanian Chalk of United Kingdom, spanning the early to late Cenomanian. Fossils with similar vertebrae and characteristically swollen teeth are also found in late Cenomanian deposits in Germany, and late Cenomanian to Santonian rocks from Kansas, Colorado, South Dakota, and Texas (see above for specific localities and references). These occurrences are all from temperate waters, which indicates a cooler environmental tolerance for this genus. The fossil record indicates an early Cenomanian origin for the genus, which likely spread to the Western Interior following the prevailing westward current of the SuperTethys throughout the Cenomanian (Caldwell and Cooper, 1999). Coniasaurus fossils have not been recovered from European deposits younger than the CTBE, implying that the European lineage may have been driven to extinction by this event. However, numerous Turonian records in the Western Interior indicate an established lineage that may have persisted to at least the Santonian (based on fragmentary remains from the Coniacian and Santonian of Kansas). A single indeterminate Colombian record in the Turonian hints that the North American lineage even radiated after the boundary event, migrating and establishing new populations in South America. The tentatively assigned dolichosaur vertebra from the CampanianMaastrichtian of Argentina (Albino, 2000) may attest to the continued evolution and radiation of the North American Coniasaurus lineage.

Overall, the fossil record of dolichosaurs shows a high degree of endemism. This is surprising, as no known physical barriers would have obstructed their potential migration. And yet, dolichosaurs are not the only group that show a surprising amount of characteristic localized faunas. An interesting correlation exists between the multiple endemic populations of dolichosaurs and that of Late Cretaceous pan-chelonioids, certain Tethyan mosasaurs, and the latest Cretaceous plesiosaurs, who all-despite a suite of marine dispersal routes-showed a high degree of specific endemism, even though they were distributed worldwide in shallow marine environments (Hirayama, 1997; Vincent et al., 2011; Bardet, 2012; Kear et al., 2013; Bardet et al., 2014). It is possible that this is related to island biogeography, and that these populations were specialized to the particular ecology surrounding an island or island system. This alludes to the danger posed to dolichosaurs by the CTBE: if these faunas were so specialized to a particular region of the Tethys, then their disappearance could have been caused by changes to, or the loss of, their particularly specialized and unique habitats.

\section{Summary}

Previously thought to be limited in space and time to the Tethys and Western Interior Seaway of the mid-Cretaceous, dolichosaurs are now understood to have a more complex history than previously reported. Current knowledge of dolichosaurs indicates a large diversity of species, despite the low number of identifiable specimens. In some areas (Mediterranean region), dolichosaurs are preserved primarily as articulated skeletons, while in others (western Europe, North America) fragmentary remains provide little diagnostic information. Though biogeographic patterns and processes remain obscured, some general patterns are clear. Early pythonomorph diversity is highest in the Western Tethys and this is the likely area of origin of ophidiomorphs, including dolichosaurs. A radiation in the late Early Cretaceous likely had early dolichosaurs expanding their range across the Tethys and making multiple independent freshwater incursions in areas as far away as Japan and Australia. The North American radiation likely happened later, in the early Late Cretaceous. An extinction event at the end of the Cenomanian may have caused the extinction or nearextinction of most dolichosaur lineages, save for an eastern Atlantic fauna, and the North American fauna. These lineages persisted and radiated in the Late Cretaceous, eventually going extinct at the Cretaceous-Tertiary boundary. We expect that future discoveries-especially in areas with tentative and fragmentary dolichosaur remains-will provide new data about the evolutionary and paleogeographical history of pythonomorph lizards. Understanding the occurrence of this group through space and time is critical to the study of their evolution and adaptation, including evolutionary drivers and their aquatic radiation.

\section{AUTHOR CONTRIBUTIONS}

MCM wrote the manuscript and performed the literature review. SP performed the literature review, provided edits on the manuscript, and wrote the part of the sections "Introduction" and "Discussion." MC critically revised the manuscript, provided funding for the study and longer-term research projects, and supervised the graduate research of MCM and SP that contributed new insights to this manuscript.

\section{FUNDING}

This study was funded in part by an NSERC Discovery Grant (\#238458), an NSERC Accelerator Grant (\#412275), and a Chair's Research Allowance to MC. The authors also thank the Vanier CGS for a scholarship to MCM.

\section{ACKNOWLEDGMENTS}

The authors thank the reviewers JS and SL for their constructive comments, and the editor $\mathrm{KB}$ for his support during the review process. Thanks to Ron Blakey for the use of his maps (www.deeptimemaps.com), which were used in the production of Figure 2. This publication is derived from a chapter from the Ph.D. thesis of MCM (Campbell Mekarski, 2017). 


\section{REFERENCES}

Albino, A. M. (2000). New record of snakes from the cretaceous of patagonia (Argentina). Geodiversitas 22, 247-253.

Alcaydé, G. (1975). Notice explicative, carte géologique de la France à 1/50 000, feuille Chinon (486), XVII-23. Orléans: Bureau de recherches géologiques et miničres.

Alonso, A. (1981). El cretáceo de la provincia de segovia (borde Norte del Sistema Central). Madrid: Universidad Complutense.

Averianov, A. O. (2001). The first find of a dolichosaur (squamata, dolichosauridae) in central Asia. Paleontol. J. 35, 525-527.

Bardet, N. (2012). Maastrichtian marine reptiles of the mediterranean tethys: a palaeobiogeographical approach. Bull. Soc. Géol. 183, 573-596. doi: 10.2113/ gssgfbull.183.6.573

Bardet, N., Falconnet, J., Fischer, V., Houssaye, A., Jouve, S., Pereda Suberbiola, X., et al. (2014). Mesozoic marine reptile palaeobiogeography in response to drifting plates. Gondwana Res. 26, 869-887. doi: 10.1016/j.gr.2014.05.005

Bardet, N., Houssaye, A., Rage, J. C., and Pereda Suberbiola, X. (2008). The cenomanian-turonian (late Cretaceous) radiation of marine squamates (Reptilia): the role of the mediterranean tethys. Bull. Soc. Géol. 179, 605-622. doi: 10.2113/gssgfbull.179.6.605

Bardet, N., Pereda Suberbiola, X., and Metais, E. (1998). Un lézard varanoïde (squamata, mosasauroidea) dans le Crétacé supérieur de touraine. Geol. France $1,69-71$.

Bardet, N., Suberbiola, X. P., and Jalil, N.-E. (2003). A new mosasauroid (Squamata) from the late cretaceous (Turonian) of morocco. Comptes Rendus Palevol 2, 607-616. doi: 10.1016/j.crpv.2003.09.006

Barroso-Barcenilla, F., Cambra-Moo, O., Escaso, F., Ortega, F., Pascual, A., PérezGarcía, A., et al. (2009). New and exceptional discovery in the upper cretaceous of the iberian peninsula: the palaeontological site of "Lo Hueco". Cuenca Spain. Cretac. Res. 30, 1268-1278. doi: 10.1016/j.cretres.2009.07.010

Bell, B. A., Murry, P. A., and Osten, L. W. (1982). Coniasaurus owen, 1850 from north america. J. Paleontol. 56, 520-524.

Bell, G. L. J. (1997). “Part IV: Mosasauridae - Introduction," in Ancient Marine Reptiles, eds J. M. Callaway, and E. L. Nicholls, (San Diego, CA: Academic Press), 281-292.

Bell, G. L. J., and Polcyn, M. J. (1996). Distribution of the lizard, Coniasaurus, in the western interior cretaceous seaway and its paleoecological implications. Geol. Soc. Am. Rocky Mt. Sect. Abstr. 28:2.

Bell, G. L. J., and Polcyn, M. J. (2005). Dallasaurus turneri, a new primitive mosasauroid from the Middle Turonian of Texas and comments on the phylogeny of Mosasauridae (Squamata). Netherlands J. Geosci. 84, 177-194. doi: 10.1017/s0016774600020965

Bilotte, M. (1980). Le gisement d'Auzas (maastrichtien des pe-tites-pyrénées). stratigr. - environnements. Bull. la Soc. d'histoire Nat. Toulouse 116, 57-63.

Blakey, R. (2008). "Gondwana paleogeography from assembly to breakup - A 500 m.y. odyssey," in Resolving the Late Paleozoic Ice Age in Time and Space. Geological Society of America Special, eds C. R. Fielding, T. D. Frank, and J. L. Isbell, (Boulder, CO: Geological Society of America), 1-28. doi: 10.1130/2008. 2441(01)

Blanco, A., Stinnesbeck, W., López-Oliva, J. G., Frey, E., Adatte, T., and Gonzalez, A. H. (2001). Vallecillo, Nuevo León: una nueva localidad fosilífera del cretácico tardío en el noreste de México. Rev. Mex. Ciencias Geol. 18, 186-199.

Blanco, J. P., Medina, P. A., and Patarroyo, P. (2004). La formación la frontera, sección vereda tóriba: una propuesta para la designación del lectoestratotipo. Geol. Colomb. 29, 23-40.

Blanco-Piñón, A., Frey, E., Stinnesbeck, W., and López-Oliva, J. G. (2002). Late cretaceous (Turonian) fish assemblage from vallecillo, northeastern mexico. Neues Jahrb. für Geol. Und Paläontologie Abhandlungen 225, 39-54. doi: 10. $1127 /$ njgpa/225/2002/39

Bolet, A., and Evans, S. E. (2012). A tiny lizard (Lepidosauria, Squamata) from the lower cretaceous of spain. Palaeontology 55, 491-500. doi: 10.1111/j.1475-4983. 2012.01145.x

Bossio, A., Foresi, L. M., Margiotta, S., Mazzei, R., Salvatorini, G., and Donia, F. (2006). Stratigrafia neogenico-quaternaria del settore nord-orientale della provincia di lecce (con rilevamento geologico alla scala 1: 25.000). Geol. Rom. $39,63-88$.
Brown, C. M., Evans, D. C., Campione, N. E., O’brien, L. J., and Eberth, D. A. (2013). Evidence for taphonomic size bias in the dinosaur park formation (Campanian, Alberta), a model mesozoic terrestrial alluvial-paralic system. Palaeogeogr. Palaeoclimatol. Palaeoecol. 372, 108-122. doi: 10.1016/j.palaeo. 2012.06.027

Buchy, M.-C., Smith, K. T., Frey, E., Stinnesbeck, W., González González, A. H., Ifrim, C., et al. (2005). Annotated catalogue of marine squamates (Reptilia) from the upper cretaceous of northeastern mexico. Netherlands J. Geosci. 84, 195-205. doi: 10.1017/S0016774600020977

Buscalioni, A. D., and Fregenal-Martinez, M. A. (2010). A holistic approach to the palaeoecology of las hoyas konservat-lagerstatte (la huerguina formation, lower cretaceous, iberian ranges, spain). J. Iber. Geol. 36, 297-326. doi: 10.5209/rev_ jige.2010.v36.n2.13

Caldwell, M. W. (1999). Description and phylogenetic relationships of a new species of coniasaurus owen, 1850 (Squamata). J. Vertebr. Paleontol. 19, 438455. doi: 10.1080/02724634.1999.10011157

Caldwell, M. W. (2000). On the aquatic squamate Dolichosaurus longicollis (Cenomanian, Cretaceous), and the evolution of elongate necks in squamates. J. Vertebr. Paleontol. 20, 720-735. doi: 10.1671/0272-4634(2000)020\%5B0720: otasdl\%5D2.0.co;2

Caldwell, M. W. (2006). A new species of Pontosaurus (Squamata, Pythonomorpha) from the upper cretaceous of lebanon and a phylogenetic analysis of pythonomorpha. Mem. Della Soc. Ital. Sci. Nat. Del Mus. Civ. Di Stor. Nat. Di Milano 34, 1-42.

Caldwell, M. W. (2012). A challenge to categories: "What, if anything, is a mosasaur?” Bull. Soc. Géol. France 183, 7-34.

Caldwell, M. W. (2019). The Origin of Snakes: Morphology and The Fossil Record. Boca Raton, Fl: CRC Press.

Caldwell, M. W., and Albino, A. M. (2001). Palaeoenvironment and palaeoecology of three cretaceous snakes: pachyophis, pachyrhachis, and dinilysia. Acta Palaeontol. Pol. 46, 203-218.

Caldwell, M. W., and Cooper, J. A. (1999). Redescription, palaeobiogeography and palaeoecology of coniasaurus crassidens owen, 1850 (Squamata) from the lower chalk (Cretaceous; Cenomanian) of SE United Kingdom. Zool. J. Linn. Soc. 127, 423-452. doi: 10.1006/zjls.1998.0161

Caldwell, M. W., and Dal Sasso, C. (2004). Soft-tissue preservation in a 95 million year old marine lizard: form, function and aquatic adaptation. J. Vertebr. Paleontol. 24, 980-985. doi: 10.1671/0272-4634(2004)024[0980:SPIAMY]2.0. $\mathrm{CO} ; 2$

Caldwell, M. W., and Lee, M. S. Y. (1997). A snake with legs from the marine cretaceous of the middle east. Nature 386, 705-709. doi: 10.1038/386705a0

Caldwell, M. W., Nydam, R. L., Palci, A., and Apesteguía, S. (2015). The oldest known snakes from the middle jurassic-lower cretaceous provide insights on snake evolution. Nat. Commun. 6:5996. doi: 10.1038/ncomms6996

Caldwell, M. W., and Palci, A. (2007). A new basal mosasauroid from the cenomanian (U. Cretaceous) of slovenia with a review of mosasauroid phylogeny and evolution. J. Vertebr. Paleontol. 27, 863-880. doi: 10.1671/02724634

Caldwell, M. W., and Palci, A. (2010). A new species of marine ophidiomorph lizard, Adriosaurus skrbinensis, from the upper cretaceous of slovenia. J. Vertebr. Paleontol. 30, 747-755. doi: 10.1080/02724631003 762963

Calligaris, R. (1988). I Rettili fossili degli "strati calcarei ittiolitici di Comeno" e dell'isola di Lesina. Atti Del Mus. Civ. Stor. Nat. Trieste 41, 85-125.

Camp, C. L. (1923). Classification of the lizards. Bull. Am. Museum Nat. Hist. 48, 289-481.

Campbell Mekarski, M. (2017). The Origin and Evolution of Aquatic Adaptations in Cretaceous Squamates. Dissertation, University of Alberta, Edmonton, AB.

Cavin, L., and Kolar-Jurkovšek, T. (2000). Stratigraphic succession of the upper cretaceous fish assemblages of Krasa (Slovenia). Geologija 43:165e195.

Chalifa, Y. (1985). Saurorhamphus judeanensis (Salmoniformes: Enchodontidae), a new longirostrine fish from the cretaceous (Cenomanian) of ein-yabrud, near jerusalem. J. Vertebr. Paleontol. 5, 181-193. doi: 10.1080/02724634.1985. 10011857

Chalifa, Y. (1989). Two new species of longirostrine fishes from the early cenomanian (Late Cretaceous) of ein-yabrud, israel, with comments on the phylogeny of the dercetidae. J. Vertebr. Paleontol. 9, 314-328. doi: 10.1080/ 02724634.1989.10011765 
Cicimurri, D. J., and Bell, G. L. J. (1996). Vertebrate fauna of the boquillas formation of brewster county, texas: a preliminary report. J. Vertebr. Paleontol. 16:28A.

Citton, P., Nicosia, U., and Sacchi, E. (2015). Updating and reinterpreting the dinosaur track record of Italy. Palaeogeogr. Palaeoclimatol. Palaeoecol. 439, 117-125. doi: 10.1016/j.palaeo.2015.01.018

Clarke, L. J., and Jenkyns, H. C. (1999). New oxygen isotope evidence for long-term cretaceous climatic change in the Southern Hemisphere. Geology 27, 699-702. doi: 10.1130/0091-7613

Cleary, T. J., Moon, B. C., Dunhill, A. M., and Benton, M. J. (2015). The fossil record of ichthyosaurs, completeness metrics and sampling biases. Palaeontology 58, 521-536. doi: 10.1111/pala.12158

Cornalia, C. (1852). Cenni geologici sull' Istria. G Dell Imperiale R Inst. Lomb. Sci. Lett. Arte Bibl. Ital. 3, 1-35.

Csiki-Sava, Z., Buffetaut, E., Ösi, A., Pereda-Suberbiola, X., and Brusatte, S. L. (2015). Island life in the cretaceous - Faunal composition, biogeography, evolution, and extinction of landliving vertebrates on the late cretaceous european archipelago. Zookeys 161, 1-161. doi: 10.3897/zookeys. 469.8439

Cumbaa, S. L., Schröder-Adams, C., Day, R. G., and Phillips, A. J. (2006). Cenomanian bonebed faunas from the northeastern margin, western interior seaway, canada. Bull. New Mex. Museum Nat. Hist. Sci. 35, 139-155.

Dadić, p (1982). Povijest egzaktnih znanosti u Hrvata: Egzaktne znanosti u Hrvata od kraja 18. stoljeća do početka 20. stoljeća. New York, NY: SNL

Dal Sasso, C., and Pinna, G. (1997). Aphanizocnemus libanensis n. gen. n. sp., a new dolichosaur (Reptilia, Varanoidea) from the upper cretaceous of lebanon. Paleontol. Lomb. della Soc. Ital. di Sci. Nat. Del Mus. Civ. di Stor. Nat. Milano new Ser. 7, 3-31.

Dal Sasso, C., and Renesto, S. (1999). Aquatic varanoid reptiles from the cenomanian (upper cretaceous) lithographic limestones of lebanon. Bergamo Riv. della Mus. Civ. Sci. Nat. 20, 63-69.

Dalla Vecchia, F. M., Venturini, S., and Tentor, M. (2002). The cenomanian (late cretaceous) konservat-lagerstätte in en nammoûra (krsrouâne province), northern lebanon. Boll. della Soc. Paleontol. Ital. 41, 51-68.

Davey, S. D., and Jenkyns, H. C. (1999). Carbon-isotope stratigraphy of shallowwater limestones and implications for the timing of late cretaceous sea-level rise and anoxic events (cenomanian-turonian of the peri-adriatic carbonate platform. croatia). Eclogae Geol. Helv. 92, 163-170.

Denne, R. A., Breyer, J. A., Callender, A. D., Hinote, R. E., Kariminia, M., Kosanke, T. H., et al. (2016). "Biostratigraphic and geochemical constraints on the stratigraphy and depositional environments of the Eagle Ford and Woodbine Groups of Texas," in the Eagle Ford Shale: a Renaissance in us. Oil Production, ed. J. A. Breyer, (Tulsa, OK: American Association of Petroleum Geologists), 110.

Dettmann, M. E., and Clifford, H. T. (2000). Gemmae of the marchantiales from the winton formation (mid-Cretaceous), eromanga basin, queensland. Mem. Queensl. Mus. 45, 285-292.

Diedrich, C. (1997). Ein dentale von Coniosaurus crassidens owen (varanoidea) aus dem ober-cenoman von halle/westf. (NW-Deutschland). Geol. Und Paläontol. Westfalen 47, 43-51.

Diedrich, C. (1999). Erster nachweis von Dolichosaurus longicollis OWEN (Varanoidea) aus dem ober-cenoman von Halle/Westf. (NW-Deutschland). N.Jb.Geol.Paläont. Mh. 6, 372-384.

Diedrich, C., Caldwell, M. W., and Gingras, M. (2011). High-resolution stratigraphy and palaeoenvironments of the intertidal flats to lagoons of the Cenomanian (upper Cretaceous) of Hvar Island, Croatia, on the Adriatic carbonate platform. Carbonates Evaporites 26, 381-399. doi: 10.1007/s13146011-0073-2

Diedrich, C. G. (2010). Huge accumulations of upper cretaceous giant ammonite shells in benthic islands of southern north sea basin of central europe. Episodes $33,164-172$.

Dutchak, A. R., and Caldwell, M. W. (2006). Redescription of Aigialosaurus dalmaticus kramberger, 1892, a cenomanian mosasauroid lizard from hvar island, croatia. Can. J. Earth Sci. 43, 1821-1834. doi: 10.1139/E06-086

Dutchak, A. R., and Caldwell, M. W. (2009). A redescription of Aigialosaurus (= Opetiosaurus) bucchichi (Kornhuber, 1901) (Squamata: Aigialosauridae) with comments on mosasauroid systematics. J. Vertebr. Paleontol. 29, 437-452. doi: $10.1671 / 039.029 .0206$
Evans, S. E., and Barbadillo, J. (1997). Early cretaceous lizards from las hoyas, spain. Zool. J. Linn. Soc. 119, 23-49. doi: 10.1111/j.1096-3642.1997.tb00134.x

Evans, S. E., and Barbadillo, L. J. (1999). A short-limbed lizard from the lower cretaceous of spain. Spec. Pap. Palaeontol. Ser. 60, 73-85.

Evans, S. E., Manabe, M., Noro, M., Isaji, S., and Yamaguchi, M. (2006). A longbodied lizard from the lower cretaceous of japan. Palaeontology 49, 1143-1165. doi: 10.1111/j.1475-4983.2006.00598.x

Everhart, M. J. (2005). Oceans of Kansas - A Natural History of the Western Interior Sea. Bloomington: Indiana University Press.

Everhart, M. J., and Darnell, M. K. (2004). Occurrence of ptychodus mammillaris in the fairport chalk member of the carlile shale of ellis county, kansas. Kansas Acad. Sci. Trans. 107, 126-130. doi: 10.1660/0022-8443(2004)107\%5B0126: oopmei\%5D2.0.co;2

Exon, N. F., and Senior, B. R. (1976). The cretaceous geology of the eromanga and surat basins. BMR J. Aust. Geol. Geophys. 1, 33-50.

Féjérváry, G. J. (1918). Contributions to a monograph on fossil varanidae and megalanidae. Ann. Hist. Musei Natl. Hungarici 16, 341-467.

Föllmi, K. B., and Delamette, M. (1991). Model simulation of mid-cretaceous ocean circulation. Science 251:94. doi: 10.1126/science.251.4989.94

Fregenal-Martínez, M., Meléndez, N., Muñoz-García, M. B., Elez, J., and de la Horra, R. (2017). The stratigraphic record of the late jurassic-early cretaceous rifting in the alto tajo-serranía de cuenca region (Iberian Ranges, Spain): genetic and structural evidences for a revision and a new lithostratigraphic proposal. Rev. Soc. Geol. España 30, 113-142.

Fuček, L., Gušić, I., Jelaska, V., Korolija, B., and Oštrić, N. (1990). Stratigrafija gornjokrednih naslaga jugoistočnog dijela Dugog otoka i njihova korelacija s istovremenim naslagama otoka Brača. Geološki Vjesn. 43, 23-33.

Fuček, L., Jelaska, V., Gušić, I., Prtoljan, B., and Ostrić, N. (1991). Padinski luronski sedimenti uvale brbišnica cove na dugom otoku. Geološki Vjesn. 44, 55-67.

Gale, A. S., Hancock, J. M., and Kennedy, W. J. (1999). Biostratigraphical and sequence correlation of the cenomanian successions in mangyshlak (W. Kazakhstan) and Crimea (Ukraine) with those in southern United Kingdom. Bull. R Des Sci. Nat. Belqique Sci. Terre 69, 67-86.

García Gonzalez, M., Mier Umana, R., Cruz Guevara, L. E., and Vásquez, M. (2009). Evaluación del Potencial Hidrocarburífero de las Cuencas Colombianas Grupo de investigación en geología de hidrocarburos y carbones. Bogotá: Universidad Industrial de Santander-Agencia Nacional de Hidrocarburos

Gardner, J. D., and Cifelli, R. L. (1999). A primitive snake from the cretaceous of utah. Spec. Pap. Palaeontol. 60, 87-100.

Gasparini, Z., Sterli, J., Parras, A., Patricio, O., Gorman, J., Salgado, L., et al. (2015). Late cretaceous reptilian biota of the la colonia formation, central patagonia, argentina: occurrences, preservation and paleoenvironments. Cretac. Res. 54, 154-168. doi: 10.1016/j.cretres.2014.11.010

Gušić, I., and Jelaska, V. (1993). Upper Cenomanian-lower Turonian sea-level rise and its consequences on the Adriatic-Dinaric carbonate platform. Geol. Rundsch. 82, 676-686. doi: 10.1007/BF00191495

Haber, A., and Polcyn, M. J. (2005). A new marine varanoid from the cenomanian of the middle east. Geol. Mijnbouw Netherlands J. Geosci. 84, 247-255. doi: $10.1017 / \mathrm{s} 001677460002103 \mathrm{x}$

Hancock, J. M., and Kauffman, E. G. (1979). The great transgressions of the late cretaceous. J. Geol. Soc. Lond. 136, 175-186. doi: 10.1144/gsjgs.136.2. 0175

Haq, B. U., Hardenbol, J., and Vail, P. R. (1988). Mesozoic and cenozoic chronostratigraphy and cycles of sea-level change. Soc. Econ. Paleontol. Mineral. Spec. Publ. 42, 71-108. doi: 10.2110/pec.88.01.0071

Hattin, D. E. (1975). Stratigraphy and depositional environment of greenhorn limestone (Upper Cretaceous) of kansas. Kansas Geol. Surv. Bull. 209, 1-128.

Hattin, D. E. (1982). Stratigraphy and depositional environment of the smoky hill chalk member, niobrara chalk (upper Cretaceous) of the type area, western Kansas. Kansas Geol. Surv. Bull. 225, 1-108.

Herak, M. (1959). Prilog geologiji i hidrogeologiji otoka Hvara. Geol. Vjesn. 12, 135-148.

Herak, M., Marinčić, S., and Polšak, A. (1976). Geologija otoka Hvara. Acta Geol. 9, 5-14.

Hirayama, R. (1997). "Distribution and diversity of cretaceous chelonioids," in Ancient Marine Reptiles, eds J. M. Callaway, and E. L. Nicholls, (San Diego, CA: Academic Press), 225-241. doi: 10.1016/b978-012155210-7/ 50013-2 
Hontecillas, D., Houssaye, A., Laplana, C., Sevilla, P., Arsuaga, J. L., PérezGonzález, A., et al. (2015). Reworked marine pythonomorph (Reptilia, Squamata) remains in late pleistocene cave deposits in central Spain. Cretac. Res. 54, 188-202. doi: 10.1016/j.cretres.2014.12.010

Houssaye, A. (2010). A new aquatic pythonomorph (Reptilia, Squamata) from the Turonian (late cretaceous) of france. Comptes Rendus Palevol. 9, 39-45. doi: $10.1016 /$ j.crpv.2009.09.002

Houssaye, A., and Bardet, N. (2013). A baby mosasauroid (Reptilia, Squamata) from the turonian of morocco - Tethysaurus "junior" discovered? Cretac. Res. 46, 208-215. doi: 10.1016/j.cretres.2013.09.010

Houssaye, A., Bardet, N., Narváez, I., and Ortega, F. (2013). Squamate finding in "Lo Hueco" (late campanian-early maastrichtian, cuenca province, spain): the second non-marine pythonomorph lizard. Palaontologische Zeitschrift 87, 415-422. doi: 10.1007/s12542-0130164-6

Huffman, M. E. (1960). Micropaleontology of Lower Portion of Boquillas Formation Near Hot Springs. Brewster County, TX: Big Bend National Park.

Isaji, S., Okazaki, H., Hirayama, R., Matsuoka, H., Barrett, P. M., Tsubamoto, T., et al. (2005). Depositional environments and taphonomy of the bone-bearing beds of the lower cretaceous kuwajima formation, tetori group, japan. Bull. Kitakyushu Museum Nat. Hist. Hum. Hist. Ser. A 3, 123-133.

Jacobs, L. L., Ferguson, K., Polcyn, M. J., and Rennison, C. (2005a). Cretaceous $\delta 13 \mathrm{C}$ stratigraphy and the age of dolichosaurs and early mosasaurs. Netherlands J. Geosci. 84, 257-268. doi: 10.1017/S0016774600021041

Jacobs, L. L., Polcyn, M. J., Taylor, L. H., and Ferguson, K. (2005b). Seasurface temperatures and palaeoenvironments of dolichosaurs and early mosasaurs. Netherlands J. Geosci. 84, 269-281. doi: 10.1017/S001677460002 1053

Jenkyns, H. C. (1991). Impact of Cretaceous sea level rise and anoxic events on the Mesozoic carbonate platform of Yugoslavia. Bull. Am. Assoc. Petrol. Geol. 75, 1007-1017.

Jenkyns, H. C., Forster, A., Schouten, S., and Sinninghe Damste, J. S. (2004). High temperatures in the late cretaceous arctic ocean. Nature 432, 888-892. doi: 10.1038 /nature 03139.1

Jenkyns, H. C., Schouten-Huibers, L., Schouten, S., and Sinninghe Damsté, J. S. (2012). Warm middle jurassic-early cretaceous high-latitude sea-surface temperatures from the southern ocean. Clim. Past 8, 215-226. doi: 10.5194/cp8-215-2012

Johnson, C. C., and Kauffman, E. G. (1990). "Originations, radiations, and extinctions of cretaceous rudistid bivalve species in the caribbean province," in Extinction Events in Earth History, eds E. G. Kauffman, and O. H. Walliser, (Berlin: Springer-Verlag), 305-321.

Jurkovšek, B., and Kolar-Jurkovšek, T. (2007). Fossil assemblages from the upper cretaceous komen and tomaj limestones of kras (Slovenia). Neues Jahrb. Für Geol. Und Paläontologie Abhandlungen 245, 83-92. doi: 10.1127/0077-7749/ 2007/0245-0083

Kauffman, E. G., and Caldwell, W. G. E. (1993). "The western interior basin in space and time," in Evolution of the Western Interior Basin. Geol. Assoc. Can. Spec, eds W. G. E. Caldwell, and E. G. Kauffman, (St. John's, NL: Geological Association of Canada), 1-30.

Kear, B. P., Ekrt, B., Prokop, J., and Georgalis, G. L. (2013). Turonian marine amniotes from the bohemian cretaceous basin, czech republic. Geol. Mag. 151, 183-198. doi: 10.1017/S0016756813000502

Kear, B. P., Fordyce, E., Hiller, N., and Siversson, M. (2017). A palaeobiogeographical synthesis of australasian mesozoic marine tetrapods. Alcheringa 42, 461-486. doi: 10.1080/03115518.2017.1397428

Kear, B. P., Long, J. A., and Martin, J. E. (2005). A review of australian mosasaur occurrences. Netherlands J. Geosci. 84, 307-313. doi: 10.1017/ s0016774600021089

Kerr, A. C. (1998). Oceanic plateau formation: a cause of mass extinction and black shale deposition around the cenomanian-turonian boundary? J. Geol. Soc. London. 155, 619-626. doi: 10.1144/gsigs.155.4.0619

Kornhuber, A. (1873). Über einen neuen fossilen Saurier aus Lesina. Hrsg. Von Der k. K. Geol. Reichsanstal, Wien 5, 75-90.

Kornhuber, A. (1893). Carsosaurus marchesetti, a new fossil lacertilian from the cretaceous formation of karst near komen. Abhandlungen Der Kais. Geol. Reichsanstalt Wien 17, 1-15.
Kornhuber, A. (1901). Opetiosaurus bucchichi: eine neue fossile eidechse aus der unteren kreide von Lesina in Dalmatien. Abhandlungen Der Kais. Geol. Reichsanstalt Wien 17, 1-24.

Kramberger, C. G. (1892). Aigialosaurus: ein neue eidechse a.d. kreideschifern der insel Lesina mit rücksicht auf die bereits beschrieben lacertiden von Comen und Lesina. Glas. Hrvat. Naravosl. Druz. 7, 74-106.

Lamolda, M. A., Gorostidi, A., and Paul, C. R. C. (1994). Quantitative estimates of calcareous nannofossil changes across the plenus mark (latest cenomanian), dover United Kingdom: implications for the generation of the cenomanianturonian boundary event. Cretac. Res. 15, 143-164. doi: 10.1006/cres.1994. 1007

Langer, W. (1961). Über das alter des fischfauna von Hvar-Lesina (Dalmatien). Neues Jahrb. Fur Geol. Und Palaontologie 5, 258-265.

Laurent, Y., Bilotte, M., and Le Loeuff, J. (2002). Late maastrichtian continental vertebrates from southwestern France: correlation with marine fauna. Palaeogeogr. Palaeoclimatol. Palaeoecol. 187, 121-135. doi: 10.1016/S00310182(02)00512-6

Laurent, Y., Cavin, L., and Bilotte, M. (1999). Découverte d'un gisement à vertébrés dans le Maastrichtien supérieur des Petites-Pyrénées. Comptes Rendus Des Sci. Ser. IIA Earth Planet. Sci. 328, 781-787. doi: 10.1016/s1251-8050(99) 80171-2

Leckie, R. M., Bralower, T. J., and Cashman, R. (2002). Oceanic anoxic events and plankton evolution: biotic response to tectonic forcing during the midCretaceous. Paleoceanogr. Paleoclimatol. 17, 13-11. doi: 10.1029/2001PA000623

Lee, M. S. Y., and Caldwell, M. W. (1998). Anatomy and relationships of Pachyrhachis problematicus, a primitive snake with hindlimbs. Philos. Trans. $R$. Soc. London Biol. Sci. 353, 1521-1552. doi: 10.1098/rstb.1998.0308

Lee, M. S. Y., and Caldwell, M. W. (2000). Adriosaurus and the affinities of mosasaurs, dolichosaurs, and snakes. J. Paleontol. 74, 915-937. doi: 10.1017/ s0022336000033102

Lee, M. S. Y., and Scanlon, J. D. (2002). The Cretaceous marine squamate mesoleptos and the origin of snakes. Bull. Nat. Hist. Museum Lond. 68, 131-142.

Lehmann, J. (1999). Integrated stratigraphy and palaeoenvironment of the cenomanian-lower turonian (Upper Cretaceous) of northern westphalia, north germany. Facies 40, 25-69. doi: 10.1007/bf02537468

Lepicard, B. (1985). Le crétacé terminal et le paléocčne basal dans les petitespyrénées et les dômes annexes. Biostratigraphie Sédimentologie Stratigr. Toulouse 4, 1-276.

Lewy, Z. (1989). Correlation of lithostratigraphic units in the upper judea group (late cenomanian-late coniacian). Israel J. Earth Sci. 38, 37-43.

Lewy, Z. (1996). The approximate position of the middle-upper cenomanian substage boundary in Israel. Israel J. Earth Sci. 45, 193-199.

Lewy, Z., and Raab, M. (1976). Mid-cretaceous stratigraphy of the middle east. Muséum Naturelle Nice Annales 4, 1-21.

Liggett, G. A., Shimada, K., Bennett, S. C., and Schumacher, B. A. (2005). Cenomanian (late cretaceous) reptiles from northwestern russell county. PaleoBios 25, 9-17.

Littler, K., Robinson, S. A., Bown, P. R., Nederbragt, A. J., and Pancost, R. D. (2011). High sea-surface temperatures during the early cretaceous epoch. Nat. Geosci. 4, 169-172. doi: 10.1038/NGEO1081

Longrich, N. R. (2016). A new species of pluridens (Mosasauridae: Halisaurinae) from the upper campanian of southern nigeria. Cretac. Res. 64, 36-44. doi: 10.1016/j.cretres.2016.03.013

Makádi, L., Caldwell, M. W., and Butler, R. J. (2012). The first freshwater mosasauroid (upper cretaceous, hungary) and a new clade of basal mosasauroids. PLoS One 7:e51781. doi: 10.1371/journal.pone.0051781

Marinčić, S. (1997). Tectonic structure of the island of Hvar (southern croatia). Geol. Croat. 50, 57-77.

McDowell, S. B., and Bogert, C. M. (1954). The systematic position of Lanthanotus and the affinities of the anguinomorphan lizards. Bull. Am. Museum Nat. Hist. 105, 1-142. doi: 10.1037/h0060165

Medizza, F., and Sorbini, L. (1980). "Il giacimento del salento (Lecce)," in Proceedings of the I vertebrati Fossili Italiani. Catalogo della Mostra, Verona.

Moreman, W. L. (1942). Paleontology of the eagle ford group of north and central texas. J. Paleontol. 16, 192-220.

Néraudeau, D., Thierry, J., and Moreau, P. (1997). Variation in echinoid biodiversity during the cenomanian-early turonian transgressive episode in charentes (France). Bull. Soc. Géol. France 168, 51-61. 
Nopcsa, F. B. (1908). Zur kenntnis der fossilen eidechsen. Beitrage Zur Palaontologie Und Geol. Osterr. Und Des Orient 21, 33-62.

Nopcsa, F. B. (1923). Eidolosaurus und Pachyophis: zwei neue neocom-reptilien. Palaeontographica 65, 96-154.

Norris, R. D., Bice, K. L., Magno, E. A., and Wilson, P. A. (2002). Jiggling the tropical thermostat in the cretaceous hothouse. Geology 30, 299-302.

Nydam, R. L., Eaton, J. G., and Sankey, J. T. (2007). New taxa of transverselytoothed lizards (Squamata: Scincomorpha) and new information on the evolutionary history of 'teiids.'. J. Paleontol. 81, 538-549. doi: 10.1666/03 097.1

Ortego, F., Sanz, J. L., Barbadillo, L. J., Buscalioni, A. C., Dieguez, C., Evans, S. E., et al. (1999). "El yacimiento de las hoyas (la cierva, cuenca): un konservatlagerstätte del cretácico inferior," in La Huella del Pasado: Fósiles de CastillaLa Mancha. Junta de Comunidades de Castilla-La Mancha, eds E. Aguirre, and I. Rabano, (Cuenca: La Cierva), 195-216.

Owen, E. (1987). "Introduction", in Fossils of the Chalk, Palaeontological Association Field Guides to Fossils: Number 2, ed. A. B. Smith (Oxford: University Printing House), 9-14.

Owen, R. (1842). Description of the remains of a bird, tortoise and lizard from the Chalk of Kent. Trans. Geol. Soc. Lond. Ser. 2, 411-413. doi: 10.1144/transgslb. 6.2 .411

Owen, R. (1850). "Description of the fossil reptiles of the chalk formation," in The Geology and Fossils of the Tertiary and Cretaceous Formations of Sussex, ed. F. Dixon, (London: Longman, Brown, Green, and Longman), 378-404.

Owen, R. (1851). A monograph on the fossil Reptilia of the Cretaceous formations. Part I. Palaeontol. Soc. Monogr. 5, 1-118.

Palci, A., and Caldwell, M. W. (2007). Vestigial forelimbs and axial elongation in a 95 Million-year-old non-snake squamate. J. Vertebr. Paleontol. 27, 1-7. doi: 10.1671/0272-4634(2007)27\%5B1:vfaaei\%5D2.0.co;2

Palci, A., and Caldwell, M. W. (2010). Redescription of acteosaurus tommasinii von meyer, 1860, and a discussion of evolutionary trends within the clade ophidiomorpha. J. Vertebr. Paleontol. 30, 94-108. doi: 10.1080/0272463090340 9139

Paparella, I., Palci, A., Nicosia, U., and Caldwell, M. W. (2018). A new fossil marine lizard with soft tissues from the late cretaceous of southern Italy. R. Soc. Open Sci. 5:172411. doi: 10.1098/rsos.172411

Páramo-Fonseca, M. E. (1994). Posición sistemática de un reptil marino con base en los restos fósiles encontrados en capas del cretácico superior en yaguará (Huila). Rev. Acad. Colomb. Ciencias Exact.Físicas Nat. 19, 63-80.

Páramo-Fonseca, M. E. (1997). ). Les Vertébrés Marins du Turonien de la Vallée Supérieure du Magdalena. Colombie: Systématique, paléoécologie et paléobiogéographie.

Parona, C. F. (1926). Richerche sulle Rudiste e su altri fossili del cretacio superiore del carso goritiano e dell'istria. Mem. Inst. Geol. Univ. Padova 7, 1-56.

Pascual, R., Goin, F. J., González, P., Ardolino, A., and Puerta, P. F. (2000). A highly derived docodont from the Patagonian Late Cretaceous: evolutionary implications for gondwanan mammals. Geodiversitas 22, 395-414.

Pereda-Suberbiola, X., Astibia, H., Murelaga, X., Elorza, J., and Gómez-Alday, J. J. (2002). Taphonomy of the late cretaceous dinosaur-bearing beds of the laño quarry (iberian peninsula). Palaeogeogr. Palaeoclimatol. Palaeoecol. 157, 247-275. doi: 10.1016/s0031-0182(99)00169-8

Peréz-González, A., Karampaglidis, T., Arsuaga, J. L., Baquedano, E., Bárez, S., Gómez, J. J., et al. (2010). “Aproximación geomorfológica a los y yacimientos del pleistoceno superior del calvero de la higuera en el valle alto del lozoya (sistema central espanol, madrid)," in Actas de la 1a Reunión de Científicos Sobre Cubiles de Hiena (y otros Grandes Carnivoros) en los Yacimientos Arqueológicos de la Península Ibérica, eds E. Baquedano, and J. Rosell, (Zona Arqueológica), 404-421

Pierce, S. E. (2003). Redescription of Pontosaurus Lesinensis and the Evaluation of Dolichosaur Interrelationships and Paleoecology. Master. Thesis, Edmonton.

Pierce, S. E., and Caldwell, M. W. (2004). Redescription and phylogenetic position of the Adriatic (upper cretaceous; cenomanian) dolichosaur Pontosaurus lesinensis (Kornhuber, 1873). J. Vertebr. Paleontol. 24, 373-386. doi: 10.1671/ 1960

Polcyn, M. J., and Bell, G. L. J. (2005). Russellosaurus coheni n. gen., n. sp., a 92 million-year-old mosasaur from Texas (USA), and the definition of the parafamily russellosaurina. Netherlands J. Geosci. Geol. Mijnb. 84, 321-333. doi: $10.1017 /$ s0016774600021107
Polcyn, M. J., Jacobs, L. L., Araújo, R., Schulp, A. S., and Mateus, O. (2014). Physical drivers of mosasaur evolution. Palaeogeogr. Palaeoclimatol. Palaeoecol. 400, 17-27. doi: 10.1016/j.palaeo.2013.05.018

Polcyn, M. J., Tchernov, E., and Jacobs, L. L. (1999). "The cretaceous biogeography of the eastern mediterranean with a description of a new basal mosasauroid fron 'ein yabrun, israel," in Proceedings of the Second Gondwanan Dinosaur Symposium, (Tokyo).

Polcyn, M. J., Tchernov, E., and Jacobs, L. L. (2003). Haasiasaurus gen. nov., a new generic name for the basal mosasauroid haasia polcyn et al., 1999. J. Vertebr. Paleontol. 23:476. doi: 10.1671/0272-4634(2003)023[0476:HGNANG]2.0.CO;2

Polšak, A., Bauer, V., and Slišković, T. (1982). Stratigraphie due crétacé supérieur de la plateforme carbonatée dans les dinarides externes. Cretac. Res. 3, 125-133. doi: 10.1016/0195-6671(82)90013-1

Polšak, A., and Leskovšek, H. (1975). Relations paleóthermométrique dans le crétacé de la yugoslavié á la base des compositions isotopiquies de l'oxygéne; refletsur l'évolution sédimentologique et paléoecologique. 9 Congr. Int. Sédiment. Indic. Sédiment. 1, 161-167.

Radovčić, J. (1973). O starosti i nalazima fosilnih riba u kredi Jadranskog pojasa. Geol. Vjesnik 25, 321-326.

Radovčić, J. (1975). Some new upper Cretaceous teleosts from Yugoslavia with special reference to localities, geology and palaeoenviroment. Palaeontol. Jugosl. Akad. Znan. Umjetn. 17, 7-55.

Radovčić, J., Tišljar, J., and Jelaska, V. (1983). "Upper Cretaceous fish-bearing platy limestones in central Dalmatia," in Contributions to Sedimentology of Some Carbonate and Clastic Units of the Coastal Dinarides, eds L. Babić, and V. Jelaska (Zagreb: International Association of Sedimentologists), 79-85.

Rage, J.-C. (1989). Le plus ancien lézard varanoïde de France. Bull. Soc. Sci. Anjou $13,19-26$.

Rage, J.-C. (2013). Mesozoic and Cenozoic squamates of Europe. Paleobiodivers. Paleoenviron. 93, 517-534. doi: 10.1007/s12549-013-0124-x

Rage, J.-C., and Escuillié, F. (2000). Un nouveau serpent bipčde du Cénomanien (Crétacé). Implications phylétiques. Comptes Rendus l'Académie Des Sci. Ser. IIA Earth Planet. Sci. 330, 513-520. doi: 10.1016/S1251-8050(00)00146-4

Rage, J.-C., and Escuillié, F. (2003). The Cenomanian: stage of hindlimbed snakes. Carnets de Géol. 2003/01, 1-11. doi: 10.4267/2042/293.

Rage, J. C., and Néraudeau, D. (2004). A new pachyostotic squamate reptile from the Cenomanian of France. Palaeontology 47, 1195-1210. doi: 10.1111/j.00310239.2004.00407.x

Rage, J. C., and Richter, A. (1994). A snake from the lower cretaceous (Barremian) of Spain; the oldest known snake. Neues Jahrb. Für Geol. Und Paläontologie. Monatshefte 1994, 561-565.

Rage, J. C., and Werner, C. (1999). Mid-Cretaceous (Cenomanian) snakes from wadi abu hashim, sudan: the earliest snake assemblage. Palaeontol. Africana 35 , $85-110$.

Rieppel, O., and Head, J. J. (2004). New specimens of the fossil snake genus eupodophis rage \& escuillé, from the cenomanian (late cretaceous) of lebanon. Mem. Ital. Sci. Soc. Nat. Hist. Mus. Civ. Stor. Nat. Milan 32, $1-26$.

Robinson, N. D. (1986). Lithostratigraphy of the chalk group of the north downs, southeast England. Proc. Geol. Assoc. 97, 141-170. doi: 10.1016/S0016-7878(86) 80066-9

Robinson Roberts, L. N., and Kirschbaum, M. A. (1995). Paleogeography and the Late Cretaceous of the Western Interior of Middle North America; coal Distribution and Sediment Accumulation. Available at: https://pubs.usgs.gov/ pp/1561/report.pdf (accessed July 3, 2017).

Sanz, J. L., Wenz, S., Yebenes, A., Estes, R., Martinez-Declos, X., Jiminez-Fuentes, E., et al. (1988). An early cretaceous faunal and floral assemblage: las hoyas fossil-site (Cuenca, Spain). Geobios 21, 611-638.

Sari, B., and Özer, S. (2009). Upper Cretaceous rudist biostratigraphy of the Bey Daglari carbonate platform, western Taurides, SW Turkey. Geobios 42, 359-380. doi: 10.1016/j.geobios.2008.10.006

Scanlon, J. D., and Hocknull, S. A. (2008). A dolichosaurid lizard from the latest Albian (mid-Cretaceous) winton formation, queensland, australia. Trans. Kansas Acad. Sci. 131-136.

Schulp, A. S., Polcyn, M. J., Mateus, O., Jacobs, L. L., and Morais, M. L. (2008). “A new species of prognathodon (squamata, mosasauridae) from the maastrichtian of angola, and the affinities of the mosasaur genus Liodon," in Proceedings of the Second Mosasaur Meeting, (London). 
Scotese, C. R. (2014). Atlas of late cretaceous maps, paleomap atlas for arcgis, volume 2, the cretaceous, maps 16 - 31, mollweide projection. Paper Presented at the PALEOMAP Project, Evanston, IL

Seeley, H. G. (1881). On remains of a small lizard from neocomian rocks of Comen, near Trieste, preserved in the Geological Museum of the University of Vienna. Q. J. Geol. Soc. Lond. 37, 52-56. doi: 10.1144/gsl.jgs.1881.037.01-04.07

Shimada, K., and Bell, G. L. J. (2006). Coniasaurus owen, 1850 (Reptilia: Squamata), from the upper cretaceous niobrara chalk of western kansas. J. Paleontol. 80, 589-593. doi: 10.1666/0022-3360(2006)80\%5B589:corsft\%5D2.0.co;2

Shimada, K., Everhart, M. J., and Ewell, K. (2007). A unique reptilian (large dolichosaurid lizard?) tooth from the upper cretaceous niobrara chalk of western kansas. Trans. Kansas Acad. Sci. 110, 213-219. doi: 10.1660/002284432007110

Shimada, K., Schumacher, B. A., Parkin, J. A., and Palermo, J. M. (2006). Fossil marine vertebrates from the lowermost greenhorn limestone (upper cretaceous: middle cenomanian) in southeastern colorado. J. Paleontol. 63, 1-45. doi: 10.1666/0022-3360(2006)80\%5B1:fmvftl\%5D2.0.co;2

Shimada, K., and Ystesund, T. K. (2007). A dolichosaurid lizard, coniasaurus cf. C. crassidens, from the upper cretaceous carlile shale in russell county, kansas. Trans. Kansas Acad. Sci. 110, 236-242. doi: 10.1098/rsos.172411

Silver, B. A. (1963). The bluebonnet member, lake waco formation (upper cretaceous), central texas-a lagoonal deposit. Baylor Geol. Stud. Bull. 4, $1-46$.

Smith, K. T., and Buchy, M.-C. (2008). A new aigialosaur (Squamata: Anguimorpha) with soft tissue remains from the Upper Cretaceous of Nuevo León. Mexico. J. Vertebr. Paleontol. 28, 85-94. doi: 10.1671/0272-4634(2008) $28 \backslash \% 5 B 85$ :anasaw $\backslash \% 5 \mathrm{D} 2.0 . \mathrm{co} ; 2$

Sorbini, L. (1978). New fish bed localities of latest campanian age (lecce-south italy). a premliminary paper. Boll. Mus. Cilv. St. Nat. 5, 607-608.

Stilwell, J. D., and Henderson, R. A. (2002). Description and paleobiogeographic significance of a rare Cenomanian molluscan faunule from bathurst island, northern australia. J. Paleontol. J. Paleont 76, 447-471. doi: 10.1666/00223360(2002)076<0447:dapsoa >2.0.co;2

Stur, D. (1891). Jahresbericht 1890. Jahrb. Der Kais. Königlichen Geol. Reichsanstalt $1,1-24$.

Tchernov, E., Rieppel, O., Zaher, H., Polcyn, M. J., and Jacobs, L. L. (2000). A fossil snake with limbs. Science 287, 2010-2012. doi: 10.1126/science.287.5460. 2010

Thurmond, J. T. (1968). A new polycotylid plesiosaur from the lake waco formation (cenomanian) of Texas. J. Paleontol. 42, 1289-1296.
Turgeon, S. C., and Creaser, R. A. (2008). Cretaceous oceanic anoxic event 2 triggered by a massive magmatic episode. Nature 454, 323-326. doi: 10.1038/ nature 07076

Udden, J. (1907). A sketch of the geology of the chisos country. Brewster County, Texas. Univ. Texas Bull. 93, 101.

Vincent, P., Bardet, N., Suberbiola, X. P., Bouya, B., Amaghzaz, M., and Meslouh, S. (2011). Zarafasaura oceanis, a new elasmosaurid (Reptilia: Sauropterygia) from the maastrichtian phosphates of morocco and the palaeobiogeography of latest cretaceous plesiosaurs. Gondwana Res. 19, 1062-1073. doi: 10.1016/j.gr.2010. 10.005

Von Loh, J. P., and Bell, G. L. (1998). Fossil reptiles from the late cretaceous greenhorn formation (late cenomanian-middle turonian) of the black hills region, south dakota. Dakoterra 5, 29-38.

von Meyer, H. (1860). Acteosaurus tommasinii aus dem schwarzen kreide-schiefer von comen am karste. Palaeontogr. Beiträge Zur Naturgeschichte Der Vor. 7, 223-231.

Vullo, R., Bernárdez, E., and Buscalioni, A. D. (2009). Vertebrates from the middle?-late cenomanian la cabaña formation (asturias, northern spain): palaeoenvironmental and palaeobiogeographic implications. Palaeogeogr. Palaeoclimatol. Palaeoecol. 276, 120-129. doi: 10.1016/j.palaeo.2009.03.004

Wan, X., Wignall, P. B., and Zhao, W. (2003). The cenomanian-turonian extinction and oceanic anoxic event: evidence from southern tibet. Palaeogeogr. Palaeoclimatol. Palaeoecol. 199, 283-298. doi: 10.1016/S0031-0182(03)00543-1

Wang, C. S., Hu, X. M., Jansa, L., Wan, X. Q., and Tao, R. (2001). The cenomanianturonian anoxic event in southern tibet. Cretac. Res. 22, 481-490. doi: 10.1006/ cres.2001.0271

Wilmsen, M. (1997). Das oberald und cenoman im nordkantabrischen becken (provinz kantabrien, nordspanien): faziesentwicklung, bio- und sequenzstratigraphie. Berliner Geowissenschaftliche Abhandlungen E23, 1-167.

Conflict of Interest Statement: The authors declare that the research was conducted in the absence of any commercial or financial relationships that could be construed as a potential conflict of interest.

Copyright (c) 2019 Campbell Mekarski, Pierce and Caldwell. This is an open-access article distributed under the terms of the Creative Commons Attribution License (CC BY). The use, distribution or reproduction in other forums is permitted, provided the original author(s) and the copyright owner(s) are credited and that the original publication in this journal is cited, in accordance with accepted academic practice. No use, distribution or reproduction is permitted which does not comply with these terms. 